\title{
Severe Eosinophilic Asthma
}

\author{
Agamemnon Bakakos, Stelios Loukides and Petros Bakakos * \\ Department of Respiratory Medicine, National and Kapodistrian University of Athens, 10561 Athens, Greece \\ * Correspondence: petros44@hotmail.com
}

Received: 25 July 2019; Accepted: 29 August 2019; Published: 2 September 2019

\begin{abstract}
Asthma is a heterogeneous disease with varying severity. Severe asthma is a subject of constant research because it greatly affects patients' quality of life, and patients with severe asthma experience symptoms, exacerbations, and medication side effects. Eosinophils, although at first considered insignificant, were later specifically associated with features of the ongoing inflammatory process in asthma, particularly in the severe case. In this review, we discuss new insights into the pathogenesis of severe asthma related to eosinophilic inflammation and the pivotal role of cytokines in a spectrum that is usually referred to as "T2-high inflammation" that accounts for almost half of patients with severe asthma. Recent literature is summarized as to the role of eosinophils in asthmatic inflammation, airway remodeling, and airway hypersensitivity. Major advances in the management of severe asthma occurred the past few years due to the new targeted biological therapies. Novel biologics that are already widely used in severe eosinophilic asthma are discussed, focusing on the choice of the right treatment for the right patient. These monoclonal antibodies primarily led to a significant reduction of asthma exacerbations, as well as improvement of lung function and patient quality of life.
\end{abstract}

Keywords: severe asthma; eosinophil; inflammation; interleukin-5 (IL-5); anti-IL-5; interleukin-4

\section{Severe Asthma and Eosinophils}

It is well established that asthma is a disease with a great spectrum of symptoms among patients and wide differences in treatment efficacy. In particular, severe asthma is noted to include various specific phenotypes and endotypes, which differ in their clinical presentation, their unique pathogenetic mechanisms, and their responsiveness to treatment [1]. In order to determine the severity of asthma, it is crucial to evaluate patients' responsiveness to the controller therapy, such as inhaled corticosteroids (ICS) and long-acting $\beta 2$ agonists (LABA). In other words, clinicians need to evaluate how difficult it is to control asthma symptoms and exacerbations [2]. Therefore, severe asthma presents a challenge as it is defined as a disease which cannot be handled by conventional means of treatment-a medium-high dose of ICS combined with LABA or even oral corticosteroids [3]. A different approach has to be taken to improve asthma outcomes in these patients, and researchers began analyzing the cellular mechanisms that characterize severe asthma. The results were quite intriguing, as they yielded a number of different "types" of severe asthma which have to be recognized and treated accordingly. Eosinophils emerged as the hallmark of a prevalent type of severe asthma, which also involves $\mathrm{T}$ cells (T helper 2 (Th2) mainly, but also type 2 innate lymphoid cells) and was labeled the T2-high endotype [4].

Eosinophils were described almost 150 years ago by Paul Ehrlich as granulocytic leucocytes with a bilobed nucleus. Their primary location is within tissue and not in the bone marrow, residing mostly in the gastrointestinal tract in normal conditions [5]. They contain numerous cationic proteins, with four being the most notable: major basic protein (MBP), eosinophil cationic protein (ECP), eosinophil peroxidase (EPO), and eosinophil-derived neurotoxin (EDN); they are mostly associated with parasitic 
infections, since they have the ability to orchestrate the immune response against helminths in a Th2 cytokine cascade, very similar to that in asthmatic patients with the Th2 endotype [6]. This cascade commences when immunoglobulin $\mathrm{E}$ ( $\mathrm{IgE}$ ) reacts with an antigen; although, in helminthic infections, the antigen is indeed threatening for the host, in asthmatic patients, IgE targets are rather innocuous agents such as tree pollen or animal fur. Nevertheless, IgE activates mast cells, macrophages, and basophils, which in turn lead to the production of histamine and other inflammatory cytokines. The ongoing inflammatory process attracts cluster of differentiation $4(\mathrm{CD} 4)^{+} \mathrm{T}$ cells and more eosinophils to the site of damage in this aberrant reaction, leading to the Th2-high endotype of severe asthma with high blood and sputum eosinophils [7].

\section{Eosinophil Production and Development in the Bone Marrow}

First of all, it is important to distinguish the two major types of eosinophils in the lungs. Even though the simplistic view we had in the past about eosinophils is still viable, recent studies showed that, except for eosinophils that emerge from the bone marrow and are directly recruited to sites of inflammation, a distinct type of eosinophil with different characteristics resides in tissues in homeostatic conditions. This eosinophil population is called "homeostatic eosinophils" (hEos) [8]. These hEos were mostly examined in mice, and they differ from the regular inflammatory eosinophils (iEos). Both of these populations are produced in the bone marrow from the $\mathrm{CD} 34^{+}$progenitor stem cells and specialized CD34 ${ }^{+}$interleukin-5 receptor (IL-5R) ${ }^{+}$hematopoietic progenitor cells via a complex activation of transcription factors, the most important being GATA-1, PU.1, and CAAT enhancer-binding proteins $\alpha$ and $\varepsilon$ [9]. Notably, the actions of GATA- 1 and PU.1 are antagonistic regarding the differentiation of other hematopoietic cells; nevertheless, they synergize when it comes to eosinophil production, as it was shown in studies where in vitro enhancement of PU.1 resulted in an amplified GATA-1 transcriptomic effect [10].

Several cytokines also take part in the development of eosinophils apart from the transcription factors previously mentioned, IL-5, IL-3, and GM-CSF(Granulocyte-macrophage colony-stimulating factor). IL-3 and GM-CSF are not selective, and they stimulate the development of other leucocytes such as neutrophils and macrophages more efficiently; however, IL- 5 solely affects eosinophils and basophils [11]. The major difference in the production and recruitment of the two eosinophil populations is that hEos are differentiated in the bone marrow semi-independently from IL-5, while iEos need IL-5 in order to be produced from their precursor cells and trafficked to the lungs [12]. This was proven in IL-5 knock-out $(\mathrm{KO})$ mice which could not produce a Th2-high response due to the lack of IL-5, but the number of hEos in the lung was only reduced by half, meaning that they could be recruited via different pathways. It also explains why, in patients treated with an anti-IL-5 agent, eosinophils can still be found in both their blood and lungs [13]. Moreover, stimulation of CD34 ${ }^{+}$progenitor cells with IL-3, IL-5, and GM-CSF resulted in an upregulation of the IL-5R in these stem cells, thus prolonging eosinophil differentiation as long as they were stimulated by IL-5 [14]. However, mice that were lacking GM-CSF/IL-3/IL-5 functions were not observed to have a complete halt of eosinophil production. Instead, these mice had the ability to produce low numbers of eosinophils, indicating that there are more unidentified factors taking part in their development [15].

Even more interesting is the observation that hEos do not take active part in the allergic inflammation, as well as halting this aberrant response. They express several genes that cannot be found in the normal iEos that take part in the immunoregulation of lung and reduce the Th2 response after contact with allergens. Mice who were stripped of the prevalent eosinophil production gene $(\triangle$ dblGATA) showed a more severe allergic reaction after contact with dust mites, proving that hEos do not participate in the inflammatory process and they also downregulate the Th2 response, most probably by inhibiting the functionality of dendritic cells [12]. 


\section{Eosinophil Migration to the Lung}

Eosinophil trafficking from the bone marrow to the lungs is the first major step of the blooming inflammatory process. Even though various chemoattractants were discovered, most of them are not selective and can also draw other leucocytes. Activated Th2 cells and type 2 innate lymphoid cells (ILC2) synthesize IL-4, IL-5, and IL-13, while eotaxin-1 (CCL11) is produced by epithelial and endothelial cells after an allergen challenge. Specifically, IL-5 and eotaxin-1 play a pivotal role in eosinophil trafficking and synergize in promoting lung eosinophilia [16]. Although IL-4 is not a direct eosinophil mediator, it is crucial in the activation of the $\operatorname{IgE}$ cascade while also promoting the development of more Th2 lymphocytes, thus sustaining the migratory process [17]. The same applies to IL-13 as it induces eotaxin production [18].

IL-5 is the most crucial cytokine not only in recruiting eosinophils but also in prolonging their survival in tissues. This was observed in IL-5 KO mice which showed a greatly reduced number of eosinophils in the lungs when compared to IL-5 transgenic mice $[19,20]$. This is largely attributed to the IL-5 receptor that is also expressed in mature eosinophils apart from their progenitors, thus being able to respond to the stimulus of the cytokine via a Janus kinase signal transducer and prolong their half-life $\left(\mathrm{T}_{1 / 2}\right)$ by almost $50 \%$ [21]. IL-5 was also administered routinely to guinea pigs over a period of time, resulting in a reduction of eosinophils in the bone marrow and a concomitant increase of their number in circulation, indicating that it clearly mobilizes them and aids their trafficking into tissues [22]. It is synthesized mostly by activated Th2 lymphocytes and in smaller proportions by eosinophils and mast cells. IL-5 is already the primary target of monoclonal antibody treatment in asthmatic patients, highlighting even more its central role in the pathogenesis of the T2-high inflammatory response. Another source of IL-5 is innate lymphocytes termed ILC-2 cells that may initiate or amplify eosinophilic inflammation. These cells may also produce other Th2-related cytokines such as IL-4, IL-9, and IL-13. That is why the cytokine pattern above is usually termed as T2 instead of Th2 [23].

Eotaxin-1 was first described as a novel component in the bronchoalveolar lavage (BAL) of guinea pigs sensitized and challenged by ovalbumin and was later isolated from human tissue as well. It was the first eosinophil-specific chemoattractant discovered until two more CC chemokines named eotaxin-2 and eotaxin-3 were isolated later on [24]. Eotaxins are produced by epithelial cells of the lung but also in lower numbers by eosinophils, mast cells, macrophages of the alveoli, vascular endothelial cells, and smooth muscle cells of the airways after stimulation by IL-4 and IL-13 [25]. Eosinophils express receptors for the CC groups of chemokines, a classic G-protein transmembrane receptor, while eotaxins interact specifically with the CCR3 receptor and synergize with IL-5 and between themselves, in order to recruit eosinophils to the lungs [26]. It should be noted that the CCR3 receptor is constantly expressed on the eosinophil membrane, but its expression is further increased after an inflammatory stimulus [27]. Characteristically, it was demonstrated that the airways of asthmatic patients have a higher number of cells producing messenger RNA (mRNA) for CCR3 and its ligands, compared to healthy individuals [28]. Other cells expressing CCR3 receptors are basophils, mast cells, Th2 cells, and eosinophil progenitor cells. Activation of the CCR3 receptor by eotaxin results in the internalization of the ligand and induces chemotaxis via calcium mobilization and actin polymerization [29]. Studies showed that all three eotaxins are upregulated after an allergen challenge and have a pivotal role in different phases of the immune response.

Eotaxin- 1 is needed in the first steps of the inflammatory response, whereas eotaxins 2 and 3 are needed to prolong eosinophil survival later on [30]. Their synergistic role is clearly demonstrated in studies between single eotaxin- 1 or eotaxin- $2 \mathrm{KO}$ mice and both eotaxin 1 and $2 \mathrm{KO}$ mice. The latter group had far fewer eosinophils in their lungs after an allergen challenge when compared to the single KO group [31]. Eotaxin-1 is also crucial in mobilizing eosinophils from the bone marrow, with its levels being correlated with the eosinophil number in blood and lungs in pig specimens. However, inhibition of IL-5 in those pigs showed that eotaxin- 1 alone cannot mobilize eosinophils from the bone marrow, thus highlighting the importance of the cooperation between those two chemokines [32]. The same applies to their mobilization from circulation to tissues, since administration of eotaxin-1 
without abolishing IL-5 effects increases blood eosinophilia but fails to increase their number in tissue. On the contrary, administration of IL-5 without abolishing eotaxin-1 demonstrated a notably higher number of tissue eosinophils, further underlining the important role of IL-5 in the tissue infiltration process [33]. Eotaxin-2 synergizes with IL-5 and drives the production of IL-13, with which it later synergizes to promote lung eosinophilia [34]. Eotaxin-3 levels start to rise at a later time, and it is thought to prolong the eosinophil recruitment in lungs [35]. The CCR3 receptor was targeted for the development of new targeted treatment of asthma, since it is expressed in all the cells taking part in the inflammatory process, making it evident that blocking the eotaxin/CCR3 axis might prove greatly important in future trials.

Eosinophils, which are found in circulation after being mobilized mostly by IL-5 and eotaxin-1 as previously mentioned, still need to migrate from the vasculature to the lung tissue. In this phase, several eosinophil-specific adhesion molecules with the most important being the $\beta 1$ integrin very late antigen (VLA-4), the vascular cell adhesion molecule (VCAM-1), and the P-selectin glycoprotein ligand (PSGL-1) play an important role [36]. VLA-4 is an integrin which is expressed on the membrane of eosinophils after a stimulus from eotaxin-1. It ligands with the VCAM-1 integrin expressed at the vasculature membrane, resulting in the activation and firm adhesion of eosinophils to it, aiding their transit from the endothelium to tissues [36]. Usage of inhibitors of the VLA-4 and VCAM-1 interaction in mice studies showed a greatly reduced inflammatory response and eosinophil number in lungs, compared to normal mice [37]. Apparently, this ligand is a selective eosinophil adhesion chemokine, since it does not cause the adhesion of other leucocytes to the endothelium; therefore, more research is needed as to whether a VLA-4/VCAM-1 inhibitor could be used in the treatment of severe eosinophilic asthma. PSGL-1 on the other hand binds to P-selectin and modulates the first steps of the interaction between eosinophils and the endothelium, more specifically the rolling and adhesion stages. It is also solely expressed by eosinophils, which means that tampering with the PSGL-1/P-selectin ligand can reduce the transit of eosinophils to tissue. Trials were conducted in mice with ablation of the P-selectin gene and, indeed, those mice had fewer eosinophils in their lungs [38]. Inhibitors targeting this selectin ligand are currently being investigated in clinical trials; however, they are yet to yield promising results.

Recent studies highlighted the fact that eosinophilopoiesis can also occur in situ in the airways of severe asthmatics, since the number of $\mathrm{CD} 34^{+}$and $\mathrm{CD} 34^{+} \mathrm{IL}-5 \mathrm{R} \alpha^{+}$hematopoietic progenitor cells was much higher in this population's sputum when compared to mild asthmatics. Even more interesting was the fact that eosinophil progenitor cells did not vanish after anti-IL-5 treatment in these patients, which means that in situ eosinophilopoiesis is an important mechanism of persistent eosinophilia in the airways [39]. This could be attributed to the action of bronchial epithelial cells which, after being triggered by an extraneous stimulus, produce several cytokines, such as IL-25 and IL-33, along with thymic stromal lymphoid proteins (TSLPs) known as alarmins. Their expression was found to be higher in the airways of asthmatic patients, while they also correlate with disease severity [40]. The T2 cascade is sustained by the production of these alarmins, since they can promote eosinophil progenitor cell recruitment and trigger T2 cells, especially ILC2 cells, in producing IL-4, IL-5, and IL-13 [41]. This persistent production of cytokines by ILC2 cells facilitates the eosinophil progenitor cell homing to the lungs and provides fertile soil for their in situ maturation, causing persistent eosinophilia in these patients [42].

\section{Eosinophilic Inflammation in the Lung}

Eosinophils are the predominant cells of the inflammatory response in the lungs, contributing greatly to two major events: the remodeling and the hyperresponsiveness of the airways (AHR). Persistent inflammation caused by eosinophils leads to constant damage of the airways. The regeneration process is not flawless and results in hypertrophy of the smooth muscles, hyperplasia of goblet cells, and deposition of extracellular matrix proteins, causing membrane thickening and fibrosis [43]. 
The damage caused at the bronchial level is attributed to the degranulation of eosinophils and the release of their toxic proteins. Degranulation can occur in three different ways: (i) exocytosis, (ii) piecemeal degranulation, and (iii) cytolysis. In exocytosis, most specifically the subtype compound exocytosis, multiple granules inside the cell fuse and are then secreted to the extracellular space. This is the classic way that eosinophils act against helminths [44]. Piecemeal degranulation was demonstrated to be the most prevalent mechanism of eosinophil degranulation in asthmatic patients. In this highly regulated mechanism, the cytoplasmic proteins are "packaged" selectively in small vesicles, and then transported to the membrane through a tubulovesicular system until they are finally released by exocytosis. Various chemokines carefully regulate this process, such as Interferon-gamma (IFN- $\gamma$ ) and eotaxin-1, with studies showing that stimulating human eosinophils with a cytokine leads to the selective release of an eosinophilic protein $[45,46]$. In cytolysis, the cell dies; however, unlike apoptosis, its granules are released in the microenvironment, fully potent and active. Eosinophils which do not undergo piecemeal degranulation release their content through cytolysis [47]. Even if these mechanisms normally exist to protect tissues from damage, in this inflammatory process, the released proteins damage the epithelium, increase vascular permeability, and activate mast cells [48].

The release of eosinophilic granules and other mediators was proven to damage the airways in multiple ways. The smooth muscles of the airways contract via the M3 receptor after being triggered by acetylcholine. The M2 receptor limits its release and acts as a regulatory mechanism [49]. Eosinophils release MBP which is an allosteric antagonist of the M2 receptor, leading to an uncontrollable stimulation of the M3 receptor by acetylcholine and, thus, to bronchoconstriction [50]. MBP and other eosinophilic proteins were also shown to damage epithelial cells in vitro in similar concentrations to those found in the lungs of asthmatic patients, further proving their toxic effects [51]. However, MBP-abolished mice were not protected from AHR, meaning that other factors also contribute to this process [52]. Leukotrienes are abundant inside eosinophils, and their release causes bronchoconstriction and activates mast cells and basophils, which also excrete prostaglandins, histamine, and more leukotrienes to support the ongoing inflammation [53]. Eosinophils may induce AHR in a more indirect way, since eosinophil-ablated mice could still develop AHR when injected with T cells producing IL-13, which was demonstrated to cause AHR despite the absence of eosinophils [54]. More studies highlighted this indirect effect on AHR, since mast cells were proven to be more important in developing AHR in patients with eosinophilic asthma [55]. Blocking both CCR3 and IL-5 experimentally could not distinguish the effects of eosinophils and mast cells in AHR, since CCR3 is expressed in both types of cells. Nevertheless, use of CCR3 antagonists showed a significant reduction of both AHR and airway remodeling in animal studies, demonstrating the importance of the CCR3/eotaxin-1 axis [56]. Genetic ablation of eosinophils in mice via the GATA-1 gene showed no protection from AHR when compared to normal mice in asthmatic models [57]. Therefore, while AHR is definitely one of the hallmarks of asthma, its correlation with eosinophils is debatable and seems to be more of a secondary effect of the generalized inflammatory process.

Nevertheless, eosinophils were proven to be one of the main factors behind airway remodeling. In a study designed with the same concept as the previous one mentioned, $\Delta$ dbl-GATA mice were challenged by allergens and compared with wild-type mice. The latter group was found to exhibit all the features of airway remodeling, whereas the eosinophil-naïve mice were protected from it [58]. Similar results were demonstrated in both IL- $5 \mathrm{KO}$ mice and patients treated with anti-IL-5 agents, proving that reducing the number of eosinophils indeed reduces the deposition of extracellular matrix proteins (ECMs) such as collagen I in the airway lumen [59-61]. Eosinophils are activated by the effect of tumor necrosis factor-alpha (TNF- $\alpha$ ) and, as recent studies showed, by IL-1beta; they secrete matrix metalloproteinase- 9 which is one of the main enzymes found in asthmatic patients, highly correlated with the remodeling process and the persistent recruitment of eosinophils [62,63]. They also are a potent resource of transforming growth factor- $\beta$ (TGF- $\beta$ ) which acts as a chemoattractant for fibroblasts and activates local fibroblasts to differentiate into myofibroblasts and even into smooth muscle cells, inducing ECM production in the meantime [64]. Mice treated with an anti TGF- $\beta$ agent did not show 
evidence of airway remodeling, even if the inflammatory process was not altered, highlighting the pivotal role of TGF- $\beta$-mostly its correlation with the thickening of the basement membranes [65]. TGF- $\beta$ is not only an eosinophil product; its mRNA was found increased in all the inflammation stages, with reports suggesting that eosinophils are its primary source in the first stages of the disease [61]. Nitric oxide (NO) is another toxic molecule secreted from eosinophils, and its levels correlate with the biomarker FeNO which is discussed later on [66]. Reactive oxygen species (ROS) are yet another product of eosinophils with clear potential to damage the airway and induce a fibrotic process [67]. Summarizing, eosinophils clearly contribute to airway remodeling, and the inhibition of eosinophil adhesion and activation may also reduce the inflammatory process and airway remodeling.

\section{Biomarkers in Severe Eosinophilic Asthma and Endotyping}

There was always a notion that the heterogeneity of asthma is due to the different phenotypes and endotypes of the disease. Nevertheless, endotyping became a necessity throughout the years; therefore, the need for specific biomarkers of every distinct type increased. These biomarkers include serum IgE, blood eosinophil levels, sputum eosinophils, and levels of exhaled nitric oxide in breath (widely known as FeNO) [68].

Sputum eosinophils are the most interesting biomarker in severe eosinophilic asthma due to the insight they provide into airway eosinophilia, despite the difficulty of collecting and analyzing them in every patient routinely. Treatment of patients based on sputum eosinophils showed a reduction of the rate of exacerbations, especially in those with severe asthma. [69] Both European Respiratory Society/American Thoracic Society (ERS/ATS) and Global Initiative for Asthma (GINA) guidelines support the use of sputum eosinophils for severe asthma management [1]. Sputum eosinophils $\geq 3 \%$ are correlated with airway eosinophilia [70]. Sputum mRNA can also be used in order to determine whether patients belong in the T2-high or the T2-low group, according to the expression of cytokines found in their sputum. Although this is a more costly method, it can "mark" candidates for biological treatments [71].

Blood eosinophils were used in the past few years as a marker for severe eosinophilic asthma requiring biological treatment with an anti-IL-5 agent, since they are correlated with sputum eosinophils. The threshold was put in several counts during trials, with the most often picked numbers being 150 cells $/ \mu \mathrm{L}$ or 300 cells $/ \mu \mathrm{L}$; however, the most important from a clinical point of view is that blood eosinophil count-an easy and inexpensive biomarker-was chosen over sputum eosinophil number for eligibility for anti-IL-5 therapy [72]. During the anti-IL-5 trials, many biomarkers were evaluated, but none were deemed superior to blood eosinophils. The use of blood eosinophil counts as a biomarker for airway eosinophilia is based upon the relationship between blood and sputum eosinophil counts [73]. However, it should be noted that, although airway eosinophils are considered to better reflect eosinophil involvement in airway inflammation, peripheral blood eosinophils do not necessarily parallel airway eosinophils. High blood eosinophil numbers present good specificity for airway eosinophilia [74,75]. On the other hand, low blood eosinophil numbers might not accurately reflect the absence of airway eosinophilia $[76,77]$. This was demonstrated in a study including children with severe asthma, in which, despite $86 \%$ of them having blood eosinophil counts within normal levels, $84 \%$ still presented airway eosinophilia [78]. It should also be taken under consideration that blood eosinophil counts are influenced by high-dose ICS and mainly oral corticosteroids (OCS) [79]. A single measurement of blood eosinophil count of at least 150 cells $/ \mu \mathrm{L}$ was shown to predict subsequent measurements on average of at least 150 cells $/ \mu \mathrm{L}$ in $85 \%$ of patients [80].

FeNO is another marker that is used commonly and can inform us about the ICS response we should expect from a patient [81]. Nevertheless, there are several protruding factors that can confuse the results, the most important being smoking, allergic rhinitis, and female gender $[82,83]$. FeNO $>50 \mathrm{ppb}$ in adults suggests the presence of Th2-high inflammation, whereas FeNO $<25 \mathrm{ppb}$ suggests a Th2-low process. In another study, it was shown that, in patients with severe asthma refractory to treatment, an FeNO level $>19 \mathrm{ppb}$ was indicative of sputum eosinophilia [84]. However, current 
guidelines from ATS/ERS do not recommend FeNO-guided management for patients with severe asthma [1]. This could be attributed to the fact that FeNO is correlated with the NO produced in asthmatic airways by other cells apart from eosinophils, such as epithelial cells and macrophages. Thus, NO cannot be solely linked to eosinophils and the need for biological treatment, and it is more likely correlated with other aspects of the Th2 inflammation [85].

Volatile organic compounds (known as VOCs) are a modern biomarker also found in exhaled breath, like FeNO, and they are bound to predict with great accuracy both eosinophil and neutrophil counts in blood, while they are also correlated with eosinophil number in BAL [86]. They are processed by a meticulous algorithm called eNOSE (electronic nose), and early research suggested that they could be superior in estimating the risk of exacerbations and insensitivity to corticosteroids [87]. A recent study demonstrated that particular VOCs (hexane and 2-hexanone) had a high classification performance for eosinophilic asthma in a large asthmatic population classified according to their sputum cell count. Moreover, the combination of FeNO, blood eosinophils, and VOCs gave a very satisfactory prediction of eosinophilic asthma with an area under the curve (AUC) of 0.9 [88]. However, more data are needed if this method is to be applied on a daily basis. Last but not least, serum periostin, which derives from epithelial cells of the lung after stimulation by IL-13, was used as a biomarker of the T2-high endotype [89]. It was used in various studies as a predictor of Th2 inflammation and, even though the BOBCAT study showed that it was superior to regular biomarkers, the follow-up studies could not support these findings [75].

A combination of biomarkers may be better than using one alone, and this trend was followed in many studies. In the U-BIOPRED cohort study, a specific endotype of severe asthma involving eosinophils was described as "late-onset asthma with past or current smoking and chronic airflow obstruction with a high blood eosinophil count" [90]. A similar endotype was discovered by both the SARP and the Leicester cohorts using blood eosinophilia as an inflammatory marker, describing "late onset asthma associated with nasal polyps and resistance to corticosteroid therapy" and "a late-onset disease along with rhinosinusitis and numerous exacerbations", respectively [91]. The majority of these patients needed oral corticosteroids to achieve control of the disease and minimize exacerbations [92]. Although endotyping may not seem simple, it reveals individual therapeutic targets by means of specific treatable traits and mechanisms, leading to precision medicine, with the aid of biomarkers. For instance, Th2-high patients with severe asthma under ICS and LABA had higher FeNO, as well as blood and sputum eosinophil counts, compared to those with Th2-low inflammation in research using the $I L-13$ genes in epithelial cells of the bronchial tree.

Concluding, it is clear that biomarkers have a role to play in guiding therapy of severe asthma. However, a combination of biomarkers may be used in order to achieve a greater predictive value. Also, new biomarkers with better correlation to specific endotypes and their respective molecular pathways need to be discovered in order to achieve optimal therapy.

\section{Anti-IL-5 Therapy in Severe Eosinophilic Asthma}

\subsection{Mepolizumab}

The story of anti-IL-5 treatment in asthma is definitely a fascinating one. Given the central role of eosinophils both in the allergic and non-allergic cascade of asthmatic inflammation, along with the fact that IL-5 is the cytokine mainly responsible for the differentiation, maturation, airway trafficking, and survival of eosinophils, the development of monoclonal antibodies against IL-5 raised high expectations for new treatment approaches, primarily in severe asthma.

However, the first studies were somewhat disappointing. In one study, mepolizumab prevented the rise in eosinophil numbers both in blood and sputum after inhaled allergen challenge, but it did not ameliorate allergen-induced asthmatic responses [93]. In another study including a small number of patients with difficult-to-treat asthma who were receiving high-dose ICS and/or oral CS, anti-IL-5 was able to reduce blood eosinophils but did not have an effect on other clinical outcomes apart from a 
small improvement in lung function - forced expiratory volume in the 1st second (FEV1) [94]. A few years later, in another study, mepolizumab was administered in a large group of not well-controlled patients with moderate to severe asthma, despite being treated with ICS and receiving four puffs of beta2-agonist daily as recue medication. Again, anti-IL-5 diminished blood eosinophils but did not manage to improve any clinically important outcome [70]. In the high-dose group, there was a trend toward reducing severe exacerbations, but the study was not powered to show such an effect. In spite of the consistent effect of anti-IL-5 in the reduction of blood eosinophils, the lack of a favorable effect in clinical asthma outcomes was obvious. These findings supported the dismal statement of the "final nail in the coffin for anti-IL-5 treatment in asthma".

However, in 2009, two small but well-designed randomized controlled trials were contracted that meant to change the road of anti-IL-5 treatment in asthma. In the first study, 20 asthmatics received either mepolizumab or placebo at five monthly intravenous infusions. These patients had corticosteroid-resistant eosinophilic asthma, and it is important to note that, although they were receiving a median dose of $10 \mathrm{mg}$ of prednisone for a mean time of nine years and a high ICS dose, they still had $>10 \%$ sputum eosinophils [95]. In the second study, 61 asthmatics received 12 infusions of either mepolizumab or placebo monthly [85]. Both studies revealed a significant reduction of exacerbations, accompanying a significant reduction in blood and sputum eosinophils. In the first study, the reduction of exacerbations occurred along with a reduction in prednisone dose. Still, there was no other clinically meaningful improvement in symptoms or lung function (FEV1) in both studies. These studies highlighted the importance of eosinophils in the pathogenesis of asthma exacerbations, but more clearly paved the way for the future of anti-IL- 5 treatment by focusing-in contrast to previous studies - on two main determinants. Firstly, the primary outcome benefit from anti-IL-5 treatment relies mainly on the reduction of exacerbations; secondly, this benefit is obvious when selecting asthmatics with persistent eosinophilic inflammation despite regular corticosteroid (inhaled and/or oral) treatment.

Apart from a clear link with exacerbations, eosinophils are also important in airway remodeling in asthma. TGF-beta derived from eosinophils is involved in this process. In a study including 24 atopic asthmatics, anti-IL-5 treatment with mepolizumab reduced airway eosinophil numbers and significantly decreased the expression of three extracellular matrix proteins (tenascin, lumican, procollagen III) in the reticular basement membrane. It also reduced the percentage and the number of eosinophils expressing TGF-beta 1 . These findings are extremely important, especially taking into consideration that the asthmatics included in this study were mild and received only short acting beta agonists (SABA) and not ICS. Firstly, these findings indicate that remodeling is present even in mild asthma, and it is driven to some degree by eosinophil-derived TGF-beta 1; secondly, anti-IL-5 can prevent this process by regulating the TGF-beta-enhanced deposition of matrix proteins through the reduction of eosinophils [60].

One of the largest studies in severe asthma, the DREAM study, including 621 patients was undertaken in order to examine the effect of mepolizumab in reducing the rate of clinically significant exacerbations. As such were defined the exacerbations that required oral corticosteroids or visit to an emergency department or hospitalization. All asthmatics had a history of at least two exacerbations requiring systemic corticosteroids in the previous year and signs of eosinophilic inflammation despite treatment. These signs were either sputum eosinophils $>3 \%$, peripheral blood eosinophils $>300 \times 10^{6} / \mathrm{L}$, FeNO $>50 \mathrm{ppb}$, or loss of asthma control after a $\leq 25 \%$ reduction in regular corticosteroid dose (inhaled or oral). The study had a duration of 52 weeks, and patients received 13 infusions of one of three doses of IV mepolizumab $(75,250$, and $750 \mathrm{mg})$. All three doses equally and significantly reduced the rate of asthma exacerbations. Moreover, they reduced the number of blood and sputum eosinophils and they were well tolerated. No improvements in FEV1 and AQLQ (asthma quality of life questionnaire) were observed, and this, in accordance with previous studies, indicated the dissociation of measures of control and exacerbations. This study also provided clinically valuable information regarding predictors of efficacy of mepolizumab treatment. The two main determinants were the baseline 
peripheral blood eosinophil number and the number of exacerbations in the previous year. Higher numbers indicated a more likely response to treatment. Other factors such as baseline FEV1, acute response to bronchodilators, IgE level, and atopic status were not associated with probability of response to mepolizumab [73].

In a following study (MENSA), 576 asthmatics treated with high-dose ICS with or without oral corticosteroids were randomized to receive either $75 \mathrm{mg}$ of mepolizumab IV, $100 \mathrm{mg}$ of mepolizumab subcutaneously (SC), or placebo every four weeks for 52 weeks. These asthmatics had at least two exacerbations requiring systemic corticosteroids the previous year and evidence of eosinophilic inflammation reflected by an eosinophil count of 150 cells/ $\mu \mathrm{L}$ at screening or above 300 cells $/ \mu \mathrm{L}$ at some time point in the previous year. The primary outcome was the annualized rate of exacerbations, and they were significantly reduced by both IV and SC mepolizumab by $47 \%$ and $53 \%$, respectively. This was the first study to show that mepolizumab was associated with a significant improvement in lung function (FEV1), quality of life (AQLQ), and asthma control (ACQ-5) [96].

Another study (SIRIUS) explored the systemic corticosteroid-sparing effect of mepolizumab. In total, 135 asthmatics with severe eosinophilic asthma were randomized to receive either mepolizumab (100 mg SC) or placebo every four weeks for 20 weeks, and the primary outcome was the percentage reduction of the oral corticosteroid dose. The evidence of eosinophilic asthma was determined-similar to MENSA — by an eosinophil count of 150 cells $/ \mu \mathrm{L}$ at screening or above 300 cells $/ \mu \mathrm{L}$ at some time point in the previous year. In contrast to the MENSA study where $25 \%$ of asthmatics received oral steroids, in SIRIUS, all of the included patients received a mean dose of $10 \mathrm{mg}$ of prednisone. This study involved a so-called optimization phase, in which a reduction of the dose of oral steroids was attempted before the start of mepolizumab, so as to establish that the patients genuinely needed this dose for their asthma control. The study showed that mepolizumab permitted the reduction of oral corticosteroid dose; moreover, despite this reduction, it also significantly reduced the rate of exacerbations and improved asthma control and quality of life (secondary outcomes in this study) [97].

In a 12-month open-label extension study of MENSA after the cessation of mepolizumab treatment, it was found that eosinophils increased both in blood and sputum, returning to pre-treatment levels within three months of cessation. As for asthma control, 12 months after the stop of medication, the exacerbation rates were similar to the pretreatment levels [98]. This study showed deterioration in exacerbation frequency after the cessation of mepolizumab that was preceded by a rebound worsening of eosinophilic inflammation.

In a post hoc analysis of the DREAM and MENSA studies, patients were stratified according to baseline blood eosinophil count in order to evaluate whether this biomarker could be used to predict response to mepolizumab. It was shown that using a threshold of 150 cells $/ \mu \mathrm{L}$ could predict a favorable outcome in reducing exacerbations. Most importantly, this reduction was higher with increasing baseline blood eosinophil count ( $52 \%$ versus placebo for those with baseline blood eosinophils $>150$ and $70 \%$ for those with baseline blood eosinophils $>500$ cells $/ \mu \mathrm{L}$ ) [99]. In a subgroup analysis of the studies DREAM, MENSA, SIRIUS, and MUSCA, it was demonstrated that asthmatics with baseline eosinophils 150-300 cells/ $\mu \mathrm{L}$ showed benefits in terms of reducing exacerbations and reducing the need for systemic corticosteroids that were clinically meaningful and comparable to patients with baseline $>300$ eosinophils/ $\mu \mathrm{L}$ [100].

In patients with severe eosinophilic asthma previously treated with omalizumab, a post hoc analysis from MENSA and SIRIUS demonstrated that the response to mepolizumab was the same regardless of previous use of omalizumab [101]. This is clinically important because a subgroup of patients eligible for mepolizumab is also eligible for omalizumab treatment. Accordingly, a lack of response to omalizumab does not preclude a favorable response to mepolizumab in such asthmatics.

Another 32-week study (OSMO) included 145 patients who were eligible for both omalizumab and mepolizumab and were not controlled with omalizumab (median time of omalizumab treatment was 29.6 months). These asthmatics were switched immediately after the last dose of omalizumab to mepolizumab and achieved significant improvement, reflected by a $64 \%$ reduction in exacerbations 
compared to the previous year, better asthma control (measured by ACQ-5), and better quality of life (measured by Saint George's respiratory questionnaire-SGRQ). These outcomes were achieved early within 8-12 weeks and were kept or even improved during the study, indicating no evidence of possible additional action of the two antibodies until the wash-out of omalizumab. This study provided support to clinical practice in terms of switching from one biologic agent to another [102].

A study (MUSCA) assessed the effect of mepolizumab in the quality of life of patients with severe eosinophilic asthma and found a significant improvement in SGRQ of 7.7 (surpassing the minimal clinically important difference of four units), with a safety profile comparable to placebo [103].

Regarding safety, in a 52-week, open-label extension study of MENSA and SIRIUS (COSMOS study), mepolizumab had a favorable long-term safety profile, without any increase in the rate of adverse events [104]. Similarly, in the COLOMBUS study, an extension of the DREAM study lasting 3.5 years with a maximum exposure of 4.5 years, mepolizumab was safe and maintained its efficacy in the reduction of exacerbations [105].

Using data from five phase III studies with mepolizumab, it was shown that few patients developed anti-drug antibodies that had no impact on safety or efficacy of mepolizumab. Only one patient (from the SIRIUS study) was positive for neutralizing antibodies, but pharmacokinetic samples were not quantifiable during follow-up. These data show the low immunogenic response of mepolizumab [106].

\subsection{Reslizumab}

Reslizumab is a humanized anti-IL-5 IgG4 monoclonal antibody that binds with high affinity to the alpha subunit of the cytokine IL-5, thus preventing the interaction with its receptor [107].

Initially, a pilot safety study including 32 asthmatics showed that reslizumab at a dose of $1 \mathrm{mg} / \mathrm{kg}$ given intravenously reduced blood and sputum eosinophils but had no effect in lung function and airway hyperresponsiveness [94]. In the following phase IIb randomized, double-blind, placebo-controlled study, 106 patients with asthma and sputum eosinophils $\geq 3 \%$ were administered reslizumab at a dose $3 \mathrm{mg} / \mathrm{kg}$ IV every four weeks. Reslizumab managed to decrease sputum eosinophils significantly and improve FEV1, as well as improve asthma control (ACQ) in those patients with nasal polyps [108].

The two main phase III studies included 953 asthmatics that were randomized to receive either reslizumab ( $3 \mathrm{mg} / \mathrm{kg} \mathrm{IV}$ ) or placebo. All included patients had a baseline peripheral blood eosinophil count of $>400$ cells $/ \mu \mathrm{L}, \mathrm{ACQ}-7>1.5$, at least $12 \%$ FEV1 reversibility, and at least one exacerbation requiring OCS in the last year; they were also on regular treatment with high-dose ICS plus additional controller with or without OCS (up to $10 \mathrm{mg}$ of prednisone). The duration of the studies was 52 weeks, and the primary outcome was the rate of exacerbations defined either as need for OCS or doubling the ICS dose. Reslizumab was effective in reducing exacerbations significantly, improving FEV1, ACQ-7, and AQLQ, as well as reducing rescue medication and blood eosinophils [109]. In a post hoc analysis of these two studies, it was demonstrated that late-onset asthma (defined as onset after the age of 40) showed a better response to reslizumab compared to early-onset asthma [110].

In conclusion, these studies showed that reslizumab at a dose of $3 \mathrm{mg} / \mathrm{kg} \mathrm{IV}$ is safe and more effective in patients with severe eosinophilic asthma and a peripheral blood eosinophil count $>400$ cells $/ \mu \mathrm{L}$.

In another study including 10 patients with oral corticosteroid-dependent asthma, weight-adjusted intravenous reslizumab was more effective in reducing sputum eosinophilia compared to fixed-dose SC mepolizumab that was administered for at least one year with inadequate response. This was associated with a greater improvement in asthma control measured by ACQ-5 [111].

\subsection{Benralizumab}

Benralizumab is a humanized, afucosylated, monoclonal antibody targeting the IL- $5 \alpha$ receptor. In comparison to anti-IL-5 monoclonal antibodies, benralizumab induces a direct, fast, and nearly complete depletion of blood eosinophils through enhanced antibody-dependent cell-mediated cytotoxicity, via natural killer cells [112]. As IL-5 receptors are expressed not only on eosinophils, but also on eosinophil progenitors and basophils, it is expected to affect all these populations. A study evaluating the effect 
of benralizumab on eosinophils in different compartments such as bone marrow, peripheral blood, sputum, and airways showed that bone marrow and peripheral blood eosinophils were completely suppressed while airway eosinophils (tissue and sputum) were also extensively depleted [113]. Two phase III trials, SIROCCO and CALIMA demonstrated that benralizumab significantly reduced the rate of asthma exacerbations in patients with severe, uncontrolled asthma and blood eosinophil counts $\geq 300$ cells $/ \mu \mathrm{L}[114,115]$. In the SIROCCO study, benralizumab administered either every four weeks or every eight weeks (after the first three doses given every four weeks) reduced the rate of exacerbations by up to $51 \%$ after 48 weeks of treatment. It also improved lung function (expressed as an increase in pre-bronchodilator FEV1) and asthma control [114]. The effect compared to placebo was greater for the eight-weekly dosage, with the potential to lower the burden of asthma and reduce costs in comparison to other biologics that need to be given on a monthly basis. In CALIMA, a study of similar design to SIROCCO with a duration of 56 weeks, it was confirmed that benralizumab reduced asthma exacerbations up to $36 \%$ in patients with severe eosinophilic asthma and blood eosinophil counts $\geq$ 300 cells/ $\mu \mathrm{L}$. Again, as found in SIROCCO, a substantial improvement in lung function and asthma symptoms was observed [115]. Although there were no direct comparisons between biologics, it seems that the increases in lung function were greater with benralizumab than with other biologics.

In both studies, benralizumab produced a direct, rapid, and nearly complete depletion of eosinophils as early as four weeks, providing support for its mechanism of action directly on the IL-5 $\alpha$ receptor, causing eosinophil apoptosis. Benralizumab depletes eosinophils directly, whereas mepolizumab and reslizumab reduce eosinophil number rather than deplete them entirely. This way, benralizumab is likely to overtake potential issues such as the induction of increased cytokine production due to cytokine-directed antibodies. A pooled analysis from the SIROCCO and CALIMA studies demonstrated that benralizumab was safe and effective in patients with severe eosinophilic asthma and blood eosinophils $>150$ cells/ $\mu \mathrm{L}$ [116].

A subsequent pooled analysis of the SIROCCO and CALIMA studies stratified patients according to baseline blood eosinophil count and by number of exacerbations (two and three or more). In this analysis, the rates of asthma exacerbations were increasingly reduced with increasing blood eosinophil thresholds and with greater exacerbation history. These reductions were even greater with a combination of high blood eosinophils and a history of more frequent exacerbations [117].

Another phase III study, ZONDA, showed that benralizumab significantly reduced the dose of oral prednisone in OCS-dependent patients, while also reducing the rate of exacerbations. All patients received oral corticosteroids for at least six months prior entering the study. The study included a run-in phase where the dose of prednisone was reduced to the minimum while maintaining asthma control, and this preceded the first administration of benralizumab. After 28 weeks, $50 \%$ of the patients managed to stop oral corticosteroids, while the likelihood of reducing the dose was four times higher in benralizumab-treated than in placebo-treated asthmatics [118].

A phase III extension study, BORA, included patients who completed the SIROCCO and CALIMA studies and evaluated the safety and tolerability of benralizumab. Interestingly, patients that received placebo in SIROCCO and CALIMA were randomized to receive benralizumab either every four weeks or every eight weeks (after administration of the first three doses every four weeks). The study confirmed the two-year safety of benralizumab as the percentage of patients experiencing adverse events was not different between BORA and the SIROCCO and CALIMA studies. No increased risk of infection was observed in patients receiving benralizumab for two years despite the long-term depletion of eosinophils. Moreover, asthmatics who were treated with benralizumab in BORA but received placebo in SIROCCO and CALIMA showed a comparable reduction in exacerbation rate with those receiving the active drug from the first year [119].

It is of high clinical importance to assess baseline characteristics in patients with severe eosinophilic asthma that may predict the response to treatment with benralizumab. In a study including patients from the SIROCCO and CALIMA phase III studies, it was shown that OCS use, nasal polyps, forced vital capacity (FVC) $<65 \%$ pred adult onset of asthma ( $>18$ years), and three or more exacerbations 
in the previous year were associated with a greater response to benrlizumab, measured either as annual exacerbation rate or change in pre-bronchodilator FEV1 for those with $>300$ eosinophils $/ \mu \mathrm{L}$. Interestingly, OCS use, nasal polyps, and FVC $<65 \%$ pred could predict a better response to benralizumab in decreasing the rate of exacerbations, even in patients with $<300$ eosinophils/ $\mu \mathrm{L}$ [120]. This study highlights the importance of assessing these clinical features when evaluating an asthmatic patient eligible for benralizumab, and adds to the already known baseline blood eosinophil count predictive information for responsiveness to treatment.

Another study assessed the effect of benralizumab treatment by stratifying patients according to atopic status (atopic or non-atopic) and IgE level (high $>150 \mathrm{kU} / \mathrm{L}$ or low $<150 \mathrm{kU} / \mathrm{L}$ ). The study again included patients from the phase III SIROCCO and CALIMA studies and demonstrated that the efficacy of benralizumab in reducing the exacerbation rate and improving lung function was not affected by atopic status and serum IgE level [121]. This is clinically important because it indicates that benralizumab is effective in patients with severe eosinophilic asthma that might be eligible for omalizumab treatment as well.

There are no head-to-head trials for direct comparison between the different anti-IL- 5 biologics. In a matching-adjusted indirect comparison, benralizumab and mepolizumab similarly reduced exacerbation rate and improved lung function. No comparison could be made between benralizumab and reslizumab due to differences in study populations [122]. Another indirect comparison demonstrated that, in patients with similar blood eosinophil counts, mepolizumab was more effective in reducing exacerbations than benralizumab and reslizumab. As for lung function, benralizumab was associated with a greater improvement in FEV1 compared to reslizumab for patients with a blood eosinophil count $>400$ cells $/ \mu \mathrm{L}$ [123]. However, all these findings of the indirect comparison trials should be viewed with caution because of the differences in study populations and in the number of exacerbations in the previous year of the included patients. Moreover, there were differences in the treatment the patients received before starting the biologic (either the ICS dose and/or OCS dose). The studies for reslizumab enrolled asthmatics with baseline blood eosinophils $>400$ cells $/ \mu \mathrm{L}$, a higher number compared to those enrolled in studies for mepolizumab and benralizumab. Accordingly, a greater effect might have been expected.

There are no studies evaluating possible co-administration of biologics with different mechanisms such as anti-IgE and anti-IL-5 for those who present a mixed phenotype (severe allergic and eosinophilic asthma). In these patients, it is logical to assess the predominant characteristics and decide which biologic to start [124].

It is suggested that anti-IL- 5 antibodies be administered for at least 16 weeks in order to assess efficacy. However, this time may be extended up to 12 months as there are some late-responders, and 16 weeks is possibly too short a length of time to evaluate reduction in exacerbations [125].

There are still some unanswered questions with major clinical importance. How long should an anti-IL-5 be prescribed in a patient with severe eosinophilic asthma? It seems that, after stopping it, there is a relapse of exacerbations following an increase in blood and sputum eosinophils, and this was shown with mepolizumab and benralizumab. This relapse of eosinophilic inflammation is compatible with a lack of long-term bone marrow suppression after discontinuation of medication $[98,119]$. Is there a rationale for moving from an anti-IL-5 antibody to an anti-IL-5 receptor antibody or vice versa? The mechanism of action is different, and benralizumab is associated with almost a depletion of blood eosinophils while mepolizumab reduces them significantly but does not deplete them. However, no difference in efficacy in any outcome (exacerbation rate, lung function) was observed. One possible explanation is that these antibodies exert their effect by reducing the eosinophil pool in the bone marrow, thus reducing exacerbations through the reduction of eosinophils that are available for mobilization and trafficking in the airways. 


\section{Anti-IL-4 therapy in Severe Asthma}

\section{Dupilumab}

Dupilumab is a fully human anti-interleukin- $4 \alpha$ receptor monoclonal antibody, recently approved for moderate-to-severe eosinophilic asthma or oral steroid-dependent asthma. It blocks interleukin-4 and interleukin-13, which are key mediators in type-2-mediated inflammation.

The first study on dupilumab included 52 asthmatics with severe eosinophilic asthma and a baseline blood eosinophil count of $>300$ cells $/ \mu \mathrm{L}$ or sputum eosinophils $>3 \%$ who were treated with medium-to-high-dose ICS plus LABA. The patients received dupilumab (300 mg SC) or placebo weekly for 12 weeks or until an exacerbation occurred. The design of the study was provocative since asthmatics discontinued LABA by week four and gradually tapered and discontinued ICS at weeks 6-9. Dupilumab was associated with an $87 \%$ reduction in exacerbations compared to placebo and also improved lung function and reduced markers of Th2 inflammation [126].

The following phase IIb study included 769 patients with severe asthma on medium-to-high ICS plus LABA, irrespective of baseline blood eosinophil count. They received $200 \mathrm{mg}$ or $300 \mathrm{mg}$ of dupilumab or placebo every two or every four weeks for a total duration of 24 weeks. Dupilumab improved FEV1 and reduced the exacerbation rate significantly in the total population and also in the subgroups of patients with less than or more than 300 eosinophils/ $\mu \mathrm{L}$ [127]. In a post hoc analysis of this study, the favorable effects of dupilumab were demonstrated regardless of the exacerbation frequency in the previous year, although treatment effects tended to be greater with higher number of exacerbations in the year prior to study entry. In another post hoc analysis of the above study, dupilumab (200 mg SC) every two or every four weeks was associated with clinically meaningful improvements in asthma control (as assessed by ACQ-5) and quality of life (assessed by AQLQ), while it also improved asthma symptoms and reduced productivity loss [128]. In another study of similar design, 1902 patients with severe uncontrolled asthma were assigned to receive dupilumab (200 or $300 \mathrm{mg}$ SC) or matched placebo every two weeks for 52 weeks. The study again confirmed the favorable effect of both doses in reducing annual exacerbation rate and improving lung function. These effects, although observed irrespective of baseline blood eosinophils, were greater in those with $>300$ cells $/ \mu$ L [129].

As with anti-IL-5 antibodies, dupilumab was assessed regarding its efficacy in reducing OCS in asthmatics with oral steroid-dependent asthma. Accordingly, 210 patients received dupilumab (300 mg) or placebo every two weeks for 24 weeks. Oral steroid doses were reduced from week four to week 20 and then remained at a stable dose for another four weeks. Dupilumab reduced oral corticosteroid dose by $70 \%$ compared to $42 \%$ reduction of placebo, and simultaneously decreased the rate of exacerbation by $59 \%$ compared to placebo; this effect was observed despite the reduction in the OCS dose. It also significantly improved lung function [130]. In the studies by Castro et al. and Rabe et al., transient eosinophilia was observed in few patients who received dupilumab.

A meta-analysis involving 3369 asthmatics from five studies concluded that treatment with dupilumab was effective in reducing exacerbations and improving lung function, asthma symptoms, asthma control and quality of life. Dupilumab was safe and well tolerated, and the most frequent adverse event was injection-site reaction [131].

Chronic rhinosinusitis with nasal polyps (CRSwNP) is often a comorbidity of severe eosinophilic asthma. In a subgroup analysis of a study involving patients with CRSwNP who received dupilumab as add-on therapy to mometasone fuorate nasal spray, those patients with comorbid asthma showed improvements not only in nasal polyp burden but also in asthma control, quality of life, and lung function [132]. 


\section{Anti-IgE Therapy in Severe Asthma}

\section{Omalizumab}

Omalizumab is a humanized monoclonal antibody that binds free $\operatorname{IgE}$ and prevents it from binding to the high-affinity IgE receptor on basophils and mast cells [133]. Omalizumab is now approved for the treatment of moderate-to-severe allergic asthma in patients $>6$ years of age. Omalizumab was the first biologic approved for use in asthma 15 years ago. To be eligible for omalizumab, the asthmatic should demonstrate sensitization to one of the perennial allergens on skin prick testing. Levels of total $\operatorname{IgE}$ combined with body weight are used to calculate the dose and the frequency of dosing. Omalizumab is administered subcutaneously either once a month or every two weeks. It was extensively studied in both clinical trials and real-world observational studies and was found to reduce the annual relative risk of asthma exacerbation by $38 \%$ and the risk of emergency visits by $47 \%$ compared with controls, according to pooled data from seven randomized studies [134]. The benefit of omalizumab in reducing exacerbations in relation to the presence of biomarkers reflective of $\mathrm{T} 2$ inflammation was evaluated in a study, showing that asthmatics with peripheral blood eosinophils $\geq 260$ cells/ $\mu \mathrm{L}$ and FeNO $\geq 19.5 \mathrm{ppb}$ had a greater reduction of exacerbations compared to those with biomarker values below the above cut-off levels [135]. Accordingly, these biomarkers could be beneficial in selecting patients who are more likely to respond to omalizumab treatment. However, more recent data from real-world studies suggest that blood eosinophil levels are not predictors of reduction in exacerbations [136,137].

\section{Other Therapies}

Thymic stromal lymphopoietin (TSLP) is produced by airway epithelial cells in response to inhaled allergens and proinflammatory stressors [138,139].

Tezepelumab is a human monoclonal antibody that binds to TSLP, inhibiting its stimulatory action on dendritic cells and innate lymphoid cells, thus preventing the induction of type 2 cytokines (e.g., IL-5, IL-4, and IL-13). One phase II, randomized, double-blind, placebo-controlled trial evaluated the efficacy and safety of tezepelumab in patients with uncontrolled asthma, despite treatment with long-acting beta-agonists and medium-to-high doses of inhaled corticosteroids. Three dose levels of subcutaneous tezepelumab were compared to placebo over 52 weeks. The primary end point was the annualized rate of asthma exacerbations. Exacerbation rates were significantly reduced in tezepelumab groups-regardless of the baseline blood eosinophil count-compared to placebo by $61 \%$ in the low-dose group, $71 \%$ in the medium-dose group, and $66 \%$ in the high-dose group. Lung function was improved irrespective of the dose, while health-related quality of life improved only in the high-dose group [140].

Prostaglandin D2 (PGD2) is mainly released from mast cells, but platelets, alveolar macrophages, Th2 cells, and dendritic cells can also produce smaller amounts of PGD2. Prostaglandin D2 contributes to T2 inflammation through binding of the G-protein-coupled receptor chemoattractant receptor-homologous molecule expressed on Th2 cells (CRTH2) [141]. Fevipiprant is an oral competitive antagonist of CRTH2.

In a phase II study, including 170 patients with mild-to-moderate persistent, allergic asthma, fevipiprant produced a significant improvement in $\mathrm{FEV}_{1} \mathrm{AUC}_{0-24}$ only in patients with high serum IgE and blood eosinophils $>300 / \mu \mathrm{L}$ [142].

In another phase II study, including 61 patients with moderate-to-severe, persistent asthma and sputum eosinophilia ( $\geq 2 \%$ ), fevipiprant produced a significant, 3.5 -fold greater decrease in sputum eosinophilia than placebo during the 12-week treatment period. In addition, fevipiprant reduced bronchial submucosal eosinophil numbers in bronchial biopsies compared to placebo. However, no change in blood eosinophil count was observed [143].

Finally, in another phase IIb study, including 1058 patients with allergic asthma uncontrolled with inhaled corticosteroids, fevipiprant—as well as montelukast—improved pre-dose FEV1 compared 
to placebo. However, no evidence of a higher efficacy in any predefined subgroup, including blood eosinophil count was observed [144].

\section{Summary}

In order to consider a biologic therapy for severe asthma, it is fundamental to firstly confirm asthma diagnosis and then solve possible problems related to non-adherence to medication, improper inhaler technique, and treatment of comorbid conditions.

For severe eosinophilic asthma, targeted therapies directed against IL-5 and IL-4 are available up to date (Table 1). These agents proved effective mainly in reducing asthma exacerbations but also in improving lung function and asthma control. It is clinically desirable that these antibodies seem to work specifically for uncontrolled asthma despite the use of daily oral corticosteroids. This led to the option of systemic steroids as the last alternative for GINA step 5, which will likely be entirely erased as a treatment option in the years to come.

Another major benefit from the use of biologics in severe asthma is the opportunity for a better insight into asthma pathophysiology mechanisms. An important but still unanswered question is whether biologics have an effect on moderate asthma or produce a disease-modifying effect. Until then, and while expecting more biologics to come (e.g., tezepelumab), we hope to gain experience and understand more from the longer use of the current anti-T2 biologics.

Table 1. Studies on biologic therapies for severe eosinophilic asthma.

\begin{tabular}{|c|c|c|c|c|}
\hline Study & Medication & Patients & Duration & Outcome \\
\hline $\begin{array}{l}\text { Pavord et al. [73] } \\
\text { (DREAM study) } \\
\text { Phase III }\end{array}$ & Mepolizumab & 621 & 52 weeks & Reduced number of exacerbations \\
\hline $\begin{array}{l}\text { Ortega et al. [96] } \\
\text { (MENSA study) } \\
\text { Phase III }\end{array}$ & Mepolizumab & 576 & 52 weeks & $\begin{array}{l}\text { Reduced number of exacerbations and improved } \\
\text { lung function (FEV1), asthma control (ACQ-5), and } \\
\text { quality of life (AQLQ) }\end{array}$ \\
\hline $\begin{array}{l}\text { Bel et al. [97] } \\
\text { (SIRIUS study) } \\
\text { Phase III }\end{array}$ & Mepolizumab & 135 & 20 weeks & $\begin{array}{l}\text { Reduced oral corticosteroid dose and number of } \\
\text { exacerbations }\end{array}$ \\
\hline $\begin{array}{l}\text { Chapman et al. [102] } \\
\text { (OSMO study) } \\
\text { Phase III }\end{array}$ & Mepolizumab & 145 & 32 weeks & $\begin{array}{c}\text { Reduced number of exacerbations and } \\
\text { improvement in asthma control (ACQ-5) and } \\
\text { quality of life (SGRQ) }\end{array}$ \\
\hline $\begin{array}{l}\text { Chupp et al. [103] } \\
\text { (MUSCA study) } \\
\text { Phase III }\end{array}$ & Mepolizumab & 551 & 24 weeks & Improvement in the SGRQ total score \\
\hline $\begin{array}{l}\text { Castro et al. [109] } \\
\text { Phase III }\end{array}$ & Reslizumab & 953 & 52 weeks & $\begin{array}{l}\text { Reduced number of exacerbations and } \\
\text { improvement in lung function (FEV1), asthma } \\
\text { control (ACQ-7), and quality of life (AQLQ) }\end{array}$ \\
\hline $\begin{array}{l}\text { Bleecker et al. [114] } \\
\text { (SIROCCO study) } \\
\text { Phase III }\end{array}$ & Benralizumab & 1205 & 48 weeks & $\begin{array}{l}\text { Reduced number of exacerbations, improved lung } \\
\text { function (FEV1), and asthma control }\end{array}$ \\
\hline $\begin{array}{l}\text { FitzGerald et al. [115] } \\
\text { (CALIMA study) } \\
\text { Phase III }\end{array}$ & Benralizumab & 1306 & 56 weeks & $\begin{array}{l}\text { Reduced number of exacerbations and improved } \\
\text { lung function (FEV1) }\end{array}$ \\
\hline $\begin{array}{l}\text { Nair et al. [118] } \\
\text { (ZONDA study) } \\
\text { Phase III }\end{array}$ & Benralizumab & 220 & 28 weeks & $\begin{array}{l}\text { Reduced oral corticosteroid dose and number of } \\
\text { exacerbations }\end{array}$ \\
\hline $\begin{array}{l}\text { Busse et al. [119] } \\
\text { (BORA study) } \\
\text { Phase III }\end{array}$ & Benralizumab & 1576 & 56 weeks & Validated 2-year safety of benralizumab use \\
\hline $\begin{array}{l}\text { Wenzel et al. [127] } \\
\text { Phase Ilb }\end{array}$ & Dupilumab & 769 & 24 weeks & $\begin{array}{c}\text { Reduced number of exacerbations and improved } \\
\text { lung function (FEV1) }\end{array}$ \\
\hline
\end{tabular}


Table 1. Cont.

\begin{tabular}{ccccc}
\hline Study & Medication & Patients & Duration & Outcome \\
\hline $\begin{array}{c}\text { Castro et al. [129] } \\
\text { Phase IIb }\end{array}$ & Dupilumab & 1902 & 52 weeks & $\begin{array}{c}\text { Reduced number of exacerbations and improved } \\
\text { lung function (FEV1) }\end{array}$ \\
\hline $\begin{array}{c}\text { Rabe et al. [130] } \\
\text { Phase III }\end{array}$ & Dupilumab & 210 & 24 weeks & $\begin{array}{c}\text { Reduced oral corticosteroid dose, number of } \\
\text { exacerbations, and improved lung function (FEV1) }\end{array}$ \\
\hline $\begin{array}{c}\text { Corren et al. [140] } \\
\text { Phase II }\end{array}$ & Tezepelumab & 550 & 52 weeks & $\begin{array}{c}\text { Improved lung function (FEV1) and reduced } \\
\text { number of exacerbations }\end{array}$ \\
\hline $\begin{array}{c}\text { Erpenbeck et al. [142] } \\
\text { Phase II }\end{array}$ & Fevipiprant & 170 & 28 days & $\begin{array}{c}\text { Improved lung function (FEV1) in patients with } \\
\text { high blood eosinophil number or high serum } \\
\text { immunoglobulin E (IgE) }\end{array}$ \\
\hline $\begin{array}{c}\text { Gonem et al. [143] } \\
\text { Phase II }\end{array}$ & Fevipiprant & 61 & 12 weeks & Reduced sputum eosinophilia \\
\hline $\begin{array}{c}\text { Bateman et al. [144] } \\
\text { Phase IIb }\end{array}$ & Fevipiprant & 1058 & 12 weeks & Improved lung function (FEV1) \\
\hline
\end{tabular}

Abbreviations: FEV1—forced expiratory volume in the first second; ACQ—asthma control questionnaire; AQLQ — asthma quality of life questionnaire; SGRQ—Saint George's respiratory questionnaire.

Author Contributions: A.B., S.L. and P.B. have substantially contributed to the conception of the work, drafted and revised the manuscript and made the final approval of the version to be published.

Conflicts of Interest: The authors declare no conflict of interest.

\section{References}

1. Chung, K.F.; Wenzel, S.E.; Brozek, J.L.; Bush, A.; Castro, M.; Sterk, P.J.; Adcock, I.M.; Bateman, E.D.; Bel, E.H.; Bleecker, E.R.; et al. International ERS/ATS guidelines on definition, evaluation and treatment of severe asthma. Eur. Respir. J. 2014, 43, 343-373. [CrossRef]

2. Reddel, H.K.; Taylor, D.R.; Bateman, E.D.; Boulet, L.-P.; Boushey, H.A.; Busse, W.W.; Casale, T.B.; Chanez, P.; Enright, P.L.; Gibson, P.G.; et al. An official American Thoracic Society/European Respiratory Society statement: Asthma control and exacerbations: Standardizing endpoints for clinical asthma trials and clinical practice. Am. J. Respir. Crit. Care Med. 2009, 180, 59-99. [CrossRef]

3. Bateman, E.D.; Boushey, H.A.; Bousquet, J.; Busse, W.W.; Clark, T.J.H.; Pauwels, R.A.; Pedersen, S.E. Can guideline-defined asthma control be achieved? The Gaining Optimal Asthma ControL study. Am. J. Respir. Crit. Care Med. 2004, 170, 836-844. [CrossRef]

4. Pavlidis, S.; Takahashi, K.; Kwong, F.N.K.; Xie, J.; Hoda, U.; Sun, K.; Elyasigomari, V.; Agapow, P.; Loza, M.; Baribaud, F.; et al. "T2-high" in severe asthma related to blood eosinophil, exhaled nitric oxide and serum periostin. Eur. Respir. J. 2019. [CrossRef]

5. Rothenberg, M.E.; Hogan, S. The eosinophil. Annu. Rev. Immunol. 2006, 24, 147-174. [CrossRef]

6. Klion, A.D.; Nutman, T.B. The role of eosinophils in host defense against helminth parasites. J. Allergy Clin. Immunol. 2004, 113, 30-37. [CrossRef]

7. Bousquet, J.; Jeffery, P.K.; Busse, W.W.; Johnson, M.; Vignola, A.M. Asthma. From bronchoconstriction to airways inflammation and remodeling. Am. J. Respir. Crit. Care Med. 2000, 161, 1720-1745. [CrossRef]

8. Marichal, T.; Mesnil, C.; Bureau, F. Homeostatic Eosinophils: Characteristics and Functions. Front. Med. 2017, 4, 101. [CrossRef]

9. Du, J.; Stankiewicz, M.J.; Liu, Y.; Xi, Q.; Schmitz, J.E.; Lekstrom-Himes, J.A.; Ackerman, S.J. Novel combinatorial interactions of GATA-1, PU.1, and C/EBPepsilon isoforms regulate transcription of the gene encoding eosinophil granule major basic protein. J. Biol. Chem. 2002, 277, 43481-43494.

10. Trivedi, S.G.; Lloyd, C.M. Eosinophils in the pathogenesis of allergic airways disease. Cell. Mol. Life Sci. 2007, 64, 1269-1289. [CrossRef]

11. Sanderson, C.J. Interleukin-5, eosinophils, and disease. Blood 1992, 79, 3101-3109.

12. Mesnil, C.; Raulier, S.; Paulissen, G.; Xiao, X.; Birrell, M.A.; Pirottin, D.; Janss, T.; Starkl, P.; Ramery, E.; Henket, M.; et al. Lung-resident eosinophils represent a distinct regulatory eosinophil subset. J. Clin. Investig. 2016, 126, 3279-3295. [CrossRef] 
13. Flood-Page, P.T.; Menzies-Gow, A.N.; Kay, A.B.; Robinson, D.S. Eosinophil's role remains uncertain as anti-interleukin-5 only partially depletes numbers in asthmatic airway. Am. J. Respir. Crit. Care Med. 2003, 167, 199-204. [CrossRef]

14. Tavernier, J.; Van der Heyden, J.; Verhee, A.; Brusselle, G.; Van Ostade, X.; Vandekerckhove, J.; North, J.; Rankin, S.M.; Kay, A.B.; Robinson, D.S. Interleukin 5 regulates the isoform expression of its own receptor alpha-subunit. Blood 2000, 95, 1600-1607.

15. Nishinakamura, R.; Miyajima, A.; Mee, P.J.; Tybulewicz, V.L.; Murray, R. Hematopoiesis in mice lacking the entire granulocyte-macrophage colony-stimulating factor/interleukin-3/interleukin-5 functions. Blood 1996, 88, 2458-2464.

16. Pease, J.E. Asthma, allergy and chemokines. Curr. Drug Targets 2006, 7, 3-12. [CrossRef]

17. Kelly-Welch, A.; Hanson, E.M.; Keegan, D. Interleukin-4 (IL-4) pathway. Sci. STKE 2005, $2005, \mathrm{~cm} 9$. [CrossRef]

18. Kelly-Welch, A.; Hanson, E.M.; Keegan, A.D. Interleukin-13 (IL-13) pathway. Sci. STKE 2005, $2005, \mathrm{cm8}$. [CrossRef]

19. Dent, L.A.; Strath, M.; Mellor, A.L.; Sanderson, C.J. Eosinophilia in transgenic mice expressing interleukin 5. J. Exp. Med. 1990, 172, 1425-1431. [CrossRef]

20. Foster, P.S.; Hogan, S.P.; Ramsay, A.J.; Matthaei, K.I.; Young, I.G. Interleukin 5 deficiency abolishes eosinophilia, airways hyperreactivity, and lung damage in a mouse asthma model. J. Exp. Med. 1996, 183, $195-201$. [CrossRef]

21. Martinez-Moczygemba, M.; Huston, D. Biology of common beta receptor-signaling cytokines: IL-3, IL-5, and GM-CSF. J. Allergy Clin. Immunol. 2003, 112, 653-665.

22. Collins, P.D.; Marleau, S.; Griffiths-Johnson, D.A.; Jose, P.J.; Williams, T.J. Cooperation between interleukin-5 and the chemokine eotaxin to induce eosinophil accumulation in vivo. J. Exp. Med. 1995, 182, 1169-1174. [CrossRef]

23. Robinson, D.; Humbert, M.; Buhl, R.; Cruz, A.A.; Inoue, H.; Korom, S.; Hanania, N.A.; Nair, P. Revisiting Type 2-high and Type 2-low airway inflammation in asthma: Current knowledge and therapeutic implications. Clin. Exp. Allergy 2017, 47, 161-175. [CrossRef]

24. Griffiths-Johnson, D.A.; Collins, P.D.; Rossi, A.G.; Jose, P.J.; Williams, T.J. The chemokine, eotaxin, activates guinea-pig eosinophils in vitro and causes their accumulation into the lung in vivo. Biochem. Biophys. Res. Commun. 1993, 197, 1167-1172. [CrossRef]

25. Gutierrez-Ramos, J.C.; Lloyd, C.; Gonzalo, J.A. Eotaxin: From an eosinophilic chemokine to a major regulator of allergic reactions. Immunol. Today 1999, 20, 500-504. [CrossRef]

26. Simson, L.; Foster, P.S. Chemokine and cytokine cooperativity: Eosinophil migration in the asthmatic response. Immunol. Cell Biol. 2000, 78, 415-422. [CrossRef]

27. Sehmi, R.; Dorman, S.; Baatjes, A.; Watson, R.; Foley, R.; Ying, S.; Robinson, D.S.; Kay, A.B.; O’Byrne, P.M.; Denburg, J.A. Allergen-induced fluctuation in CC chemokine receptor 3 expression on bone marrow CD34+ cells from asthmatic subjects: Significance for mobilization of haemopoietic progenitor cells in allergic inflammation. Immunology 2003, 109, 536-546. [CrossRef]

28. Ying, S.; Meng, Q.; Zeibecoglou, K.; Robinson, D.S.; Macfarlane, A.; Humbert, M.; Kay, A.B. Eosinophil chemotactic chemokines (eotaxin, eotaxin-2, RANTES, monocyte chemoattractant protein-3 (MCP-3), and $\mathrm{MCP}-4$ ), and C-C chemokine receptor 3 expression in bronchial biopsies from atopic and nonatopic (Intrinsic) asthmatics. J. Immunol. 1999, 163, 6321-6329.

29. Zimmermann, N.; Conkright, J.J.; Rothenberg, M.E. CC chemokine receptor-3 undergoes prolonged ligand-induced internalization. J. Biol. Chem. 1999, 274, 12611-12618. [CrossRef]

30. Ravensberg, A.J.; Ricciardolo, F.L.M.; van Schadewijk, A.; Rabe, K.F.; Sterk, P.J.; Hiemstra, P.S.; Mauad, T. Eotaxin-2 and eotaxin-3 expression is associated with persistent eosinophilic bronchial inflammation in patients with asthma after allergen challenge. J. Allergy Clin. Immunol. 2005, 115, 779-785. [CrossRef]

31. Pope, S.M.; Zimmermann, N.; Stringer, K.F.; Karow, M.L.; Rothenberg, M.E. The eotaxin chemokines and CCR3 are fundamental regulators of allergen-induced pulmonary eosinophilia. J. Immunol. 2005, 175, 5341-5350. [CrossRef] 
32. Humbles, A.A.; Conroy, D.M.; Marleau, S.; Rankin, S.M.; Palframan, R.T.; Proudfoot, A.E.I.; Wells, T.N.C.; Li, D.; Jeffery, P.K.; Griffiths-Johnson, D.A.; et al. Kinetics of eotaxin generation and its relationship to eosinophil accumulation in allergic airways disease: Analysis in a guinea pig model in vivo. J. Exp. Med. 1997, 186, 601-612. [CrossRef]

33. Mould, A.W.; Matthaei, K.I.; Young, I.G.; Foster, P.S. Relationship between interleukin-5 and eotaxin in regulating blood and tissue eosinophilia in mice. J. Clin. Investig. 1997, 99, 1064-1071. [CrossRef]

34. Mattes, J.; Foster, P.S. Regulation of eosinophil migration and Th2 cell function by IL-5 and eotaxin. Curr. Drug Targets Inflamm. Allergy 2003, 2, 169-174. [CrossRef]

35. Kalomenidis, I.; Stathopoulos, G.T.; Barnette, R.; Guo, Y.; Peebles, R.S.; Blackwell, T.S.; Light, R.W. Eotaxin-3 and interleukin-5 pleural fluid levels are associated with pleural fluid eosinophilia in post-coronary artery bypass grafting pleural effusions. Chest 2005, 127, 2094-2100. [CrossRef]

36. Jia, G.-Q.; Gonzalo, J.-A.; Hidalgo, A.; Wagner, D.; Cybulsky, M.; Gutierrez-Ramos, J.C. Selective eosinophil transendothelial migration triggered by eotaxin via modulation of Mac-1/ICAM-1 and VLA-4/VCAM-1 interactions. Int. Immunol. 1999, 11, 1-10. [CrossRef]

37. Koo, G.C.; Shah, K.; Ding, G.J.F.; Xiao, J.Y.; Wnek, R.; Doherty, G.; Tong, X.C.; Pepinsky, R.B.; Lin, K.-C.; Hagmann, W.K. A small molecule very late antigen-4 antagonist can inhibit ovalbumin-induced lung inflammation. Am. J. Respir. Crit. Care Med. 2003, 167, 1400-1409. [CrossRef]

38. Broide, D.H.; Sullivan, S.; Gifford, T.; Sriramarao, P. Inhibition of pulmonary eosinophilia in P-selectin- and ICAM-1-deficient mice. Am. J. Respir. Cell Mol. Biol. 1998, 18, 218-225. [CrossRef]

39. Sehmi, R.; Smith, S.G.; Kjarsgaard, M.; Radford, K.; Boulet, L.P.; Lemiere, C.; Prazma, C.M.; Ortega, H.; Martin, J.G.; Nair, P. Role of local eosinophilopoietic processes in the development of airway eosinophilia in prednisone-dependent severe asthma. Clin. Exp. Allergy 2016, 46, 793-802. [CrossRef]

40. Mitchell, P.D.; O'Byrne, P.M. Biologics and the lung: TSLP and other epithelial cell-derived cytokines in asthma. Pharmacol. Ther. 2017, 169, 104-112. [CrossRef]

41. Fallon, P.G.; Ballantyne, S.J.; Mangan, N.E.; Barlow, J.L.; Dasvarma, A.; Hewett, D.R.; McIlgorm, A.; Jolin, H.E.; McKenzie, A.N. Identification of an interleukin (IL)-25-dependent cell population that provides IL-4, IL-5, and IL-13 at the onset of helminth expulsion. J. Exp. Med. 2006, 203, 1105-1116. [CrossRef]

42. Smith, S.G.; Chen, R.; Kjarsgaard, M.; Huang, C.; Oliveria, J.P.; O’Byrne, P.M.; Gauvreau, G.M.; Boulet, L.P.; Lemiere, C.; Martin, J.; et al. Increased numbers of activated group 2 innate lymphoid cells in the airways of patients with severe asthma and persistent airway eosinophilia. J. Allergy Clin. Immunol. 2016, 137, 75-86 e8. [CrossRef]

43. Chakir, J.; Shannon, J.; Molet, S.; Fukakusa, M.; Elias, J.; Laviolette, M.; Boulet, L.P.; Hamid, Q. Airway remodeling-associated mediators in moderate to severe asthma: Effect of steroids on TGF-beta, IL-11, IL-17, and type I and type III collagen expression. J. Allergy Clin. Immunol. 2003, 111, 1293-1298. [CrossRef]

44. Hafez, I.; Stolpe, A.; Lindau, M. Compound exocytosis and cumulative fusion in eosinophils. J. Biol. Chem. 2003, 278, 44921-44928. [CrossRef]

45. Lacy, P.; Mahmudi-Azer, S.; Bablitz, B.; Hagen, S.C.; Velazquez, J.R.; Man, S.F.; Moqbel, R. Rapid mobilization of intracellularly stored RANTES in response to interferon-gamma in human eosinophils. Blood 1999, 94, 23-32.

46. Carmo, L.A.; Bonjour, K.; Ueki, S.; Neves, J.S.; Liu, L.; Spencer, L.A.; Dvorak, A.M.; Weller, P.F.; Melo, R.C. CD63 is tightly associated with intracellular, secretory events chaperoning piecemeal degranulation and compound exocytosis in human eosinophils. J. Leukoc. Biol. 2016, 100, 391-401. [CrossRef]

47. Saffari, H.; Hoffman, L.H.; Peterson, K.A.; Fang, J.C.; Leiferman, K.M.; Pease, L.F., 3rd; Gleich, G.J. Electron microscopy elucidates eosinophil degranulation patterns in patients with eosinophilic esophagitis. J. Allergy Clin. Immunol. 2014, 133, 1728-1734. [CrossRef]

48. Piliponsky, A.M.; Gleich, G.J.; Bar, I.; Levi-Schaffer, F. Effects of eosinophils on mast cells: A new pathway for the perpetuation of allergic inflammation. Mol. Immunol. 2002, 38, 1369. [CrossRef]

49. Fryer, A.D.; Maclagan, J. Muscarinic inhibitory receptors in pulmonary parasympathetic nerves in the guinea-pig. Br. J. Pharmacol. 1984, 83, 973-978. [CrossRef]

50. Jacoby, D.B.; Gleich, G.J.; Fryer, A.D. Human eosinophil major basic protein is an endogenous allosteric antagonist at the inhibitory muscarinic M2 receptor. J. Clin. Investig. 1993, 91, 1314-1318. [CrossRef] 
51. Gleich, G.J.; Flavahan, N.A.; Fujisawa, T.; Vanhoutte, P.M. The eosinophil as a mediator of damage to respiratory epithelium: A model for bronchial hyperreactivity. J. Allergy Clin. Immunol. 1988, 81, 776-781. [CrossRef]

52. Denzler, K.L.; Farmer, S.C.; Crosby, J.R.; Borchers, M.; Cieslewicz, G.; Larson, K.A.; Cormier-Regard, S.; Lee, N.A.; Lee, J.J. Eosinophil major basic protein-1 does not contribute to allergen-induced airway pathologies in mouse models of asthma. J. Immunol. 2000, 165, 5509-5517. [CrossRef]

53. Kay, A.B. Mediators of hypersensitivity and inflammatory cells in the pathogenesis of bronchial asthma. Eur. J. Respir. Dis. Suppl. 1983, 129, 1-44.

54. Mattes, J.; Yang, M.; Mahalingam, S.; Kuehr, J.; Webb, D.C.; Simson, L.; Hogan, S.P.; Koskinen, A.; McKenzie, A.N.; Dent, L.A.; et al. Intrinsic defect in T cell production of interleukin (IL)-13 in the absence of both IL-5 and eotaxin precludes the development of eosinophilia and airways hyperreactivity in experimental asthma. J. Exp. Med. 2002, 195, 1433-1444. [CrossRef]

55. Bradding, O.; Brightling, C. Mast cell infiltration of airway smooth muscle in asthma. Respir. Med. 2007, 101, 1045-1047. [CrossRef]

56. Wegmann, M.; Goggel, R.; Sel, S.; Sel, S.; Erb, K.J.; Kalkbrenner, F.; Renz, H.; Garn, H. Effects of a low-molecular-weight CCR-3 antagonist on chronic experimental asthma. Am. J. Respir. Cell Mol. Biol. 2007, 36, 61-67. [CrossRef]

57. Siegle, J.S.; Hansbro, N.; Herbert, C.; Yang, M.; Foster, P.S.; Kumar, R.K. Airway hyperreactivity in exacerbation of chronic asthma is independent of eosinophilic inflammation. Am. J. Respir. Cell Mol. Biol. 2006, 35, 565-570. [CrossRef]

58. Humbles, A.A.; Lloyd, C.M.; McMillan, S.J.; Friend, D.S.; Xanthou, G.; McKenna, E.E.; Ghiran, S.; Gerard, N.P.; Yu, C.; Orkin, S.H.; et al. A critical role for eosinophils in allergic airways remodeling. Science 2004, 305, 1776-1779. [CrossRef]

59. Kay, A.B.; Phipps, S.; Robinson, D.S. A role for eosinophils in airway remodelling in asthma. Trends Immunol. 2004, 25, 477-482. [CrossRef]

60. Flood-Page, P.; Menzies-Gow, A.; Phipps, S.; Ying, S.; Wangoo, A.; Ludwig, M.S.; Barnes, N.; Robinson, D.; Kay, A.B. Anti-IL-5 treatment reduces deposition of ECM proteins in the bronchial subepithelial basement membrane of mild atopic asthmatics. J. Clin. Investig. 2003, 112, 1029-1036. [CrossRef]

61. Tanaka, H.; Komai, M.; Nagao, K.; Ishizaki, M.; Kajiwara, D.; Takatsu, K.; Delespesse, G.; Nagai, H. Role of interleukin-5 and eosinophils in allergen-induced airway remodeling in mice. Am. J. Respir. Cell Mol. Biol. 2004, 31, 62-68. [CrossRef]

62. Esnault, S.; Kelly, E.A.; Johnson, S.H.; DeLain, L.P.; Haedt, M.J.; Noll, A.L.; Sandbo, N.; Jarjour, N.N. Matrix Metalloproteinase-9-Dependent Release of IL-1beta by Human Eosinophils. Mediat. Inflamm. 2019, 2019, 7479107. [CrossRef]

63. Schwingshackl, A.; Duszyk, M.; Brown, N.; Moqbel, R. Human eosinophils release matrix metalloproteinase-9 on stimulation with TNF-alpha. J. Allergy Clin. Immunol. 1999, 104, 983-989. [CrossRef]

64. Wicks, J.; Haitchi, H.M.; Holgate, S.T.; Davies, D.E.; Powell, R.M. Enhanced upregulation of smooth muscle related transcripts by TGF beta2 in asthmatic (myo) fibroblasts. Thorax 2006, 61, 313-319. [CrossRef]

65. McMillan, S.J.; Xanthou, G.; Lloyd, C.M. Manipulation of allergen-induced airway remodeling by treatment with anti-TGF-beta antibody: Effect on the Smad signaling pathway. J. Immunol. 2005, 174, 5774-5780. [CrossRef]

66. Roos, A.B.; Mori, M.; Gronneberg, R.; Osterlund, C.; Claesson, H.E.; Wahlstrom, J.; Grunewald, J.; Eklund, A.; Erjefalt, J.S.; Lundberg, J.O.; et al. Elevated exhaled nitric oxide in allergen-provoked asthma is associated with airway epithelial iNOS. PLoS ONE 2014, 9, e90018. [CrossRef]

67. MacPherson, J.C.; Comhair, S.A.; Erzurum, S.C.; Klein, D.F.; Lipscomb, M.F.; Kavuru, M.S.; Samoszuk, M.K.; Hazen, S.L. Eosinophils are a major source of nitric oxide-derived oxidants in severe asthma: Characterization of pathways available to eosinophils for generating reactive nitrogen species. J. Immunol. 2001, 166, 5763-5772. [CrossRef]

68. Chung, K.F. Asthma phenotyping: A necessity for improved therapeutic precision and new targeted therapies. J. Intern. Med. 2016, 279, 192-204. [CrossRef]

69. Petsky, H.L.; Cates, C.J.; Kew, K.M.; Chang, A.B. Tailoring asthma treatment on eosinophilic markers (exhaled nitric oxide or sputum eosinophils): A systematic review and meta-analysis. Thorax 2018, 73, 1110-1119. [CrossRef] 
70. Flood-Page, P.; Swenson, C.; Faiferman, I.; Matthews, J.; Williams, M.; Brannick, L.; Robinson, D.; Wenzel, S.; Busse, W.; Hansel, T.T.; et al. A study to evaluate safety and efficacy of mepolizumab in patients with moderate persistent asthma. Am. J. Respir. Crit. Care Med. 2007, 176, 1062-1071. [CrossRef]

71. Seys, S.F.; Grabowski, M.; Adriaensen, W.; Decraene, A.; Dilissen, E.; Vanoirbeek, J.A.; Dupont, L.J.; Ceuppens, J.L.; Bullens, D.M. Sputum cytokine mapping reveals an 'IL-5, IL-17A, IL-25-high' pattern associated with poorly controlled asthma. Clin. Exp. Allergy 2013, 43, 1009-1017. [CrossRef]

72. Pouliquen, I.J.; Kornmann, O.; Barton, S.V.; Price, J.A.; Ortega, H.G. Characterization of the relationship between dose and blood eosinophil response following subcutaneous administration of mepolizumab. Int. J. Clin. Pharmacol. Ther. 2015, 53, 1015-1027. [CrossRef]

73. Pavord, I.D.; Korn, S.; Howarth, P.; Bleecker, E.R.; Buhl, R.; Keene, O.N.; Ortega, H.; Chanez, P. Mepolizumab for severe eosinophilic asthma (DREAM): A multicentre, double-blind, placebo-controlled trial. Lancet 2012, 380, 651-659. [CrossRef]

74. Fowler, S.J.; Tavernier, G.; Niven, R. High blood eosinophil counts predict sputum eosinophilia in patients with severe asthma. J. Allergy Clin. Immunol. 2015, 135, 822-824. [CrossRef]

75. Wagener, A.H.; de Nijs, S.B.; Lutter, R.; Sousa, A.R.; Weersink, E.J.; Bel, E.H.; Sterk, P.J. External validation of blood eosinophils, $\mathrm{FE}(\mathrm{NO})$ and serum periostin as surrogates for sputum eosinophils in asthma. Thorax 2015, 70, 115-120. [CrossRef]

76. Hastie, A.T.; Moore, W.C.; Li, H.; Rector, B.M.; Ortega, V.E.; Pascual, R.M.; Peters, S.P.; Meyers, D.A.; Bleecker, E.R.; National Heart, L.; et al. Biomarker surrogates do not accurately predict sputum eosinophil and neutrophil percentages in asthmatic subjects. J. Allergy Clin. Immunol. 2013, 132, 72-80. [CrossRef]

77. Korevaar, D.A.; Westerhof, G.A.; Wang, J.; Cohen, J.F.; Spijker, R.; Sterk, P.J.; Bel, E.H.; Bossuyt, P.M. Diagnostic accuracy of minimally invasive markers for detection of airway eosinophilia in asthma: A systematic review and meta-analysis. Lancet Respir. Med. 2015, 3, 290-300. [CrossRef]

78. Ullmann, N.; Bossley, C.J.; Fleming, L.; Silvestri, M.; Bush, A.; Saglani, S. Blood eosinophil counts rarely reflect airway eosinophilia in children with severe asthma. Allergy 2013, 68, 402-406. [CrossRef]

79. Yancey, S.W.; Keene, O.N.; Albers, F.C.; Ortega, H.; Bates, S.; Bleecker, E.R.; Pavord, I. Biomarkers for severe eosinophilic asthma. J. Allergy Clin. Immunol. 2017, 140, 1509-1518. [CrossRef]

80. Katz, L.E.; Gleich, G.J.; Hartley, B.F.; Yancey, S.W.; Ortega, H.G. Blood eosinophil count is a useful biomarker to identify patients with severe eosinophilic asthma. Ann. Am. Thorac. Soc. 2014, 11, 531-536. [CrossRef]

81. Dweik, R.A.; Boggs, P.B.; Erzurum, S.C.; Irvin, C.G.; Leigh, M.W.; Lundberg, J.O.; Olin, A.C.; Plummer, A.L.; Taylor, D.R.; American Thoracic Society Committee on Interpretation of Exhaled Nitric Oxide Levels (FENO) for Clinical Applications. An official ATS clinical practice guideline: Interpretation of exhaled nitric oxide levels (FENO) for clinical applications. Am. J. Respir. Crit. Care Med. 2011, 184, 602-615. [CrossRef]

82. Kostikas, K.; Minas, M.; Papaioannou, A.I.; Papiris, S.; Dweik, R.A. Exhaled nitric oxide in asthma in adults: The end is the beginning? Curr. Med. Chem. 2011, 18, 1423-1431. [CrossRef]

83. Zuiker, R.G.; Boot, J.D.; Calderon, C.; Piantone, A.; Petty, K.; de Kam, M.; Diamant, Z. Sputum induction with hypertonic saline reduces fractional exhaled nitric oxide in chronic smokers and non-smokers. Respir. Med. 2010, 104, 917-920. [CrossRef]

84. Tseliou, E.; Bessa, V.; Hillas, G.; Delimpoura, V.; Papadaki, G.; Roussos, C.; Papiris, S.; Bakakos, P.; Loukides, S. Exhaled nitric oxide and exhaled breath condensate $\mathrm{pH}$ in severe refractory asthma. Chest 2010, 138, 107-113. [CrossRef]

85. Haldar, P.; Brightling, C.E.; Hargadon, B.; Gupta, S.; Monteiro, W.; Sousa, A.; Marshall, R.P.; Bradding, P.; Green, R.H.; Wardlaw, A.J.; et al. Mepolizumab and exacerbations of refractory eosinophilic asthma. N. Engl. J. Med. 2009, 360, 973-984. [CrossRef]

86. Diamant, Z.; Vijverberg, S.; Alving, K.; Bakirtas, A.; Bjermer, L.; Custovic, A.; Dahlen, S.E.; Gaga, M.; Gerth van Wijk, R.; Del Giacco, S.; et al. Towards clinically applicable biomarkers for asthma-An EAACI position paper. Allergy 2019. [CrossRef]

87. Brinkman, P.; van de Pol, M.A.; Gerritsen, M.G.; Bos, L.D.; Dekker, T.; Smids, B.S.; Sinha, A.; Majoor, C.J.; Sneeboer, M.M.; Knobel, H.H.; et al. Exhaled breath profiles in the monitoring of loss of control and clinical recovery in asthma. Clin. Exp. Allergy 2017, 47, 1159-1169. [CrossRef]

88. Schleich, F.N.; Zanella, D.; Stefanuto, P.H.; Bessonov, K.; Smolinska, A.; Dallinga, J.W.; Henket, M.; Paulus, V.; Guissard, F.; Graff, S.; et al. Exhaled Volatile Organic Compounds are Able to Discriminate between Neutrophilic and Eosinophilic Asthma. Am. J. Respir. Crit. Care Med. 2019. [CrossRef] 
89. Simpson, J.L.; Yang, I.A.; Upham, J.W.; Reynolds, P.N.; Hodge, S.; James, A.L.; Jenkins, C.; Peters, M.J.; Jia, G.; Holweg, C.T.; et al. Periostin levels and eosinophilic inflammation in poorly-controlled asthma. BMC Pulm. Med. 2016, 16, 67. [CrossRef]

90. Lefaudeux, D.; De Meulder, B.; Loza, M.J.; Peffer, N.; Rowe, A.; Baribaud, F.; Bansal, A.T.; Lutter, R.; Sousa, A.R.; Corfield, J.; et al. U-BIOPRED clinical adult asthma clusters linked to a subset of sputum omics. J. Allergy Clin. Immunol. 2017, 139, 1797-1807. [CrossRef]

91. Wu, W.; Bleecker, E.; Moore, W.; Busse, W.W.; Castro, M.; Chung, K.F.; Calhoun, W.J.; Erzurum, S.; Gaston, B.; Israel, E.; et al. Unsupervised phenotyping of Severe Asthma Research Program participants using expanded lung data. J. Allergy Clin. Immunol. 2014, 133, 1280-1288. [CrossRef]

92. Buhl, R.; Humbert, M.; Bjermer, L.; Chanez, P.; Heaney, L.G.; Pavord, I.; Quirce, S.; Virchow, J.C.; Holgate, S.; expert group of the European Consensus Meeting for Severe Eosinophilic Asthma. Severe eosinophilic asthma: A roadmap to consensus. Eur. Respir. J. 2017. [CrossRef]

93. Leckie, M.J.; ten Brinke, A.; Khan, J.; Diamant, Z.; O'Connor, B.J.; Walls, C.M.; Mathur, A.K.; Cowley, H.C.; Chung, K.F.; Djukanovic, R.; et al. Effects of an interleukin-5 blocking monoclonal antibody on eosinophils, airway hyper-responsiveness, and the late asthmatic response. Lancet 2000, 356, 2144-2148. [CrossRef]

94. Kips, J.C.; O’Connor, B.J.; Langley, S.J.; Woodcock, A.; Kerstjens, H.A.; Postma, D.S.; Danzig, M.; Cuss, F.; Pauwels, R.A. Effect of SCH55700, a humanized anti-human interleukin-5 antibody, in severe persistent asthma: A pilot study. Am. J. Respir. Crit. Care Med. 2003, 167, 1655-1659. [CrossRef]

95. Nair, P.; Pizzichini, M.M.; Kjarsgaard, M.; Inman, M.D.; Efthimiadis, A.; Pizzichini, E.; Hargreave, F.E.; O'Byrne, P.M. Mepolizumab for prednisone-dependent asthma with sputum eosinophilia. N. Engl. J. Med. 2009, 360, 985-993. [CrossRef]

96. Ortega, H.G.; Liu, M.C.; Pavord, I.D.; Brusselle, G.G.; FitzGerald, J.M.; Chetta, A.; Humbert, M.; Katz, L.E.; Keene, O.N.; Yancey, S.W.; et al. Mepolizumab treatment in patients with severe eosinophilic asthma. N. Engl. J. Med. 2014, 371, 1198-1207. [CrossRef]

97. Bel, E.H.; Wenzel, S.E.; Thompson, P.J.; Prazma, C.M.; Keene, O.N.; Yancey, S.W.; Ortega, H.G.; Pavord, I.D.; SIRIUS Investigators. Oral glucocorticoid-sparing effect of mepolizumab in eosinophilic asthma. N. Engl. J. Med. 2014, 371, 1189-1197. [CrossRef]

98. Haldar, P.; Brightling, C.E.; Singapuri, A.; Hargadon, B.; Gupta, S.; Monteiro, W.; Bradding, P.; Green, R.H.; Wardlaw, A.J.; Ortega, H.; et al. Outcomes after cessation of mepolizumab therapy in severe eosinophilic asthma: A 12-month follow-up analysis. J. Allergy Clin. Immunol. 2014, 133, 921-923. [CrossRef]

99. Ortega, H.G.; Yancey, S.W.; Mayer, B.; Gunsoy, N.B.; Keene, O.N.; Bleecker, E.R.; Brightling, C.E.; Pavord, I.D. Severe eosinophilic asthma treated with mepolizumab stratified by baseline eosinophil thresholds: A secondary analysis of the DREAM and MENSA studies. Lancet Respir. Med. 2016, 4, 549-556. [CrossRef]

100. Yancey, S.W.; Bradford, E.S.; Keene, O.N. Disease burden and efficacy of mepolizumab in patients with severe asthma and blood eosinophil counts of $>/=150-300$ cells/muL. Respir. Med. 2019, 151, 139-141. [CrossRef]

101. Magnan, A.; Bourdin, A.; Prazma, C.M.; Albers, F.C.; Price, R.G.; Yancey, S.W.; Ortega, H. Treatment response with mepolizumab in severe eosinophilic asthma patients with previous omalizumab treatment. Allergy 2016, 71, 1335-1344. [CrossRef]

102. Chapman, K.R.; Albers, F.C.; Chipps, B.; Munoz, X.; Devouassoux, G.; Bergna, M.; Galkin, D.; Azmi, J.; Mouneimne, D.; Price, R.G.; et al. The clinical benefit of mepolizumab replacing omalizumab in uncontrolled severe eosinophilic asthma. Allergy 2019. [CrossRef]

103. Chupp, G.L.; Bradford, E.S.; Albers, F.C.; Bratton, D.J.; Wang-Jairaj, J.; Nelsen, L.M.; Trevor, J.L.; Magnan, A.; Ten Brinke, A. Efficacy of mepolizumab add-on therapy on health-related quality of life and markers of asthma control in severe eosinophilic asthma (MUSCA): A randomised, double-blind, placebo-controlled, parallel-group, multicentre, phase 3b trial. Lancet Respir. Med. 2017, 5, 390-400. [CrossRef]

104. Lugogo, N.; Domingo, C.; Chanez, P.; Leigh, R.; Gilson, M.J.; Price, R.G.; Yancey, S.W.; Ortega, H.G. Long-term Efficacy and Safety of Mepolizumab in Patients with Severe Eosinophilic Asthma: A Multi-center, Open-label, Phase IIIb Study. Clin. Ther. 2016, 38, 2058-2070. [CrossRef]

105. Khatri, S.; Moore, W.; Gibson, P.G.; Leigh, R.; Bourdin, A.; Maspero, J.; Barros, M.; Buhl, R.; Howarth, P.; Albers, F.C.; et al. Assessment of the long-term safety of mepolizumab and durability of clinical response in patients with severe eosinophilic asthma. J. Allergy Clin. Immunol. 2019, 143, 1742-1751. [CrossRef] 
106. Ortega, H.G.; Meyer, E.; Brusselle, G.; Asano, K.; Prazma, C.M.; Albers, F.C.; Mallett, S.A.; Yancey, S.W.; Gleich, G.J. Update on immunogenicity in severe asthma: Experience with mepolizumab. J. Allergy Clin. Immunol. Pract. 2019. [CrossRef]

107. Egan, R.W.; Athwal, D.; Bodmer, M.W.; Carter, J.M.; Chapman, R.W.; Chou, C.C.; Cox, M.A.; Emtage, J.S.; Fernandez, X.; Genatt, N.; et al. Effect of Sch 55700, a humanized monoclonal antibody to human interleukin-5, on eosinophilic responses and bronchial hyperreactivity. Arzneimittelforschung 1999, 49, 779-790. [CrossRef]

108. Castro, M.; Mathur, S.; Hargreave, F.; Boulet, L.P.; Xie, F.; Young, J.; Wilkins, H.J.; Henkel, T.; Nair, P.; Res-5Study, G. Reslizumab for poorly controlled, eosinophilic asthma: A randomized, placebo-controlled study. Am. J. Respir. Crit. Care Med. 2011, 184, 1125-1132. [CrossRef]

109. Castro, M.; Zangrilli, J.; Wechsler, M.E.; Bateman, E.D.; Brusselle, G.G.; Bardin, P.; Murphy, K.; Maspero, J.F.; O'Brien, C.; Korn, S. Reslizumab for inadequately controlled asthma with elevated blood eosinophil counts: Results from two multicentre, parallel, double-blind, randomised, placebo-controlled, phase 3 trials. Lancet Respir. Med. 2015, 3, 355-366. [CrossRef]

110. Brusselle, G.; Germinaro, M.; Weiss, S.; Zangrilli, J. Reslizumab in patients with inadequately controlled late-onset asthma and elevated blood eosinophils. Pulm. Pharmacol. Ther. 2017, 43, 39-45. [CrossRef]

111. Mukherjee, M.; Aleman Paramo, F.; Kjarsgaard, M.; Salter, B.; Nair, G.; LaVigne, N.; Radford, K.; Sehmi, R.; Nair, P. Weight-adjusted Intravenous Reslizumab in Severe Asthma with Inadequate Response to Fixed-Dose Subcutaneous Mepolizumab. Am. J. Respir. Crit. Care Med. 2018, 197, 38-46. [CrossRef]

112. Kolbeck, R.; Kozhich, A.; Koike, M.; Peng, L.; Andersson, C.K.; Damschroder, M.M.; Reed, J.L.; Woods, R.; Dall'acqua, W.W.; Stephens, G.L.; et al. MEDI-563, a humanized anti-IL-5 receptor alpha mAb with enhanced antibody-dependent cell-mediated cytotoxicity function. J. Allergy Clin. Immunol. 2010, 125, 1344-1353 e2. [CrossRef]

113. Laviolette, M.; Gossage, D.L.; Gauvreau, G.; Leigh, R.; Olivenstein, R.; Katial, R.; Busse, W.W.; Wenzel, S.; $\mathrm{Wu}, \mathrm{Y}$; Datta, V.; et al. Effects of benralizumab on airway eosinophils in asthmatic patients with sputum eosinophilia. J. Allergy Clin. Immunol. 2013, 132, 1086-1096 e5. [CrossRef]

114. Bleecker, E.R.; FitzGerald, J.M.; Chanez, P.; Papi, A.; Weinstein, S.F.; Barker, P.; Sproule, S.; Gilmartin, G.; Aurivillius, M.; Werkstrom, V.; et al. Efficacy and safety of benralizumab for patients with severe asthma uncontrolled with high-dosage inhaled corticosteroids and long-acting beta2-agonists (SIROCCO): A randomised, multicentre, placebo-controlled phase 3 trial. Lancet 2016, 388, 2115-2127. [CrossRef]

115. FitzGerald, J.M.; Bleecker, E.R.; Nair, P.; Korn, S.; Ohta, K.; Lommatzsch, M.; Ferguson, G.T.; Busse, W.W.; Barker, P.; Sproule, S.; et al. Benralizumab, an anti-interleukin-5 receptor alpha monoclonal antibody, as add-on treatment for patients with severe, uncontrolled, eosinophilic asthma (CALIMA): A randomised, double-blind, placebo-controlled phase 3 trial. Lancet 2016, 388, 2128-2141. [CrossRef]

116. Goldman, M.; Hirsch, I.; Zangrilli, J.G.; Newbold, P.; Xu, X. The association between blood eosinophil count and benralizumab efficacy for patients with severe, uncontrolled asthma: Subanalyses of the Phase III SIROCCO and CALIMA studies. Curr. Med. Res. Opin. 2017, 33, 1605-1613. [CrossRef]

117. FitzGerald, J.M.; Bleecker, E.R.; Menzies-Gow, A.; Zangrilli, J.G.; Hirsch, I.; Metcalfe, P.; Newbold, P.; Goldman, M. Predictors of enhanced response with benralizumab for patients with severe asthma: Pooled analysis of the SIROCCO and CALIMA studies. Lancet Respir. Med. 2018, 6, 51-64. [CrossRef]

118. Nair, P.; Wenzel, S.; Rabe, K.F.; Bourdin, A.; Lugogo, N.L.; Kuna, P.; Barker, P.; Sproule, S.; Ponnarambil, S.; Goldman, M.; et al. Oral Glucocorticoid-Sparing Effect of Benralizumab in Severe Asthma. N. Engl. J. Med. 2017, 376, 2448-2458. [CrossRef]

119. Busse, W.W.; Bleecker, E.R.; FitzGerald, J.M.; Ferguson, G.T.; Barker, P.; Sproule, S.; Olsson, R.F.; Martin, U.J.; Goldman, M.; BORA Study Investigators. Long-term safety and efficacy of benralizumab in patients with severe, uncontrolled asthma: 1-year results from the BORA phase 3 extension trial. Lancet Respir. Med. 2019, 7, 46-59. [CrossRef]

120. Bleecker, E.R.; Wechsler, M.E.; FitzGerald, J.M.; Menzies-Gow, A.; Wu, Y.; Hirsch, I.; Goldman, M.; Newbold, P.; Zangrilli, J.G. Baseline patient factors impact on the clinical efficacy of benralizumab for severe asthma. Eur. Respir. J. 2018, 52. [CrossRef]

121. Chipps, B.E.; Newbold, P.; Hirsch, I.; Trudo, F.; Goldman, M. Benralizumab efficacy by atopy status and serum immunoglobulin E for patients with severe, uncontrolled asthma. Ann. Allergy Asthma Immunol. 2018, 120, 504-511. [CrossRef] 
122. Bourdin, A.; Husereau, D.; Molinari, N.; Golam, S.; Siddiqui, M.K.; Lindner, L.; Xu, X. Matching-adjusted indirect comparison of benralizumab versus interleukin-5 inhibitors for the treatment of severe asthma: A systematic review. Eur. Respir. J. 2018, 52. [CrossRef]

123. Busse, W.; Chupp, G.; Nagase, H.; Albers, F.C.; Doyle, S.; Shen, Q.; Bratton, D.J.; Gunsoy, N.B. Anti-IL-5 treatments in patients with severe asthma by blood eosinophil thresholds: Indirect treatment comparison. J. Allergy Clin. Immunol. 2019, 143, 190-200. [CrossRef]

124. Zervas, E.; Samitas, K.; Papaioannou, A.I.; Bakakos, P.; Loukides, S.; Gaga, M. An algorithmic approach for the treatment of severe uncontrolled asthma. ERJ Open Res. 2018, 4. [CrossRef]

125. Difficult-to-Treat and Severe Asthma in Adolescent and Adult Patients Diagnosis and Management. 2019, A GINA Pocket Guide for Health Professionals. Available online: www.ginasthma.org (accessed on 30 April 2019.).

126. Wenzel, S.; Ford, L.; Pearlman, D.; Spector, S.; Sher, L.; Skobieranda, F.; Wang, L.; Kirkesseli, S.; Rocklin, R.; Bock, B.; et al. Dupilumab in persistent asthma with elevated eosinophil levels. N. Engl. J. Med. 2013, 368, 2455-2466. [CrossRef]

127. Wenzel, S.; Castro, M.; Corren, J.; Maspero, J.; Wang, L.; Zhang, B.; Pirozzi, G.; Sutherland, E.R.; Evans, R.R.; Joish, V.N.; et al. Dupilumab efficacy and safety in adults with uncontrolled persistent asthma despite use of medium-to-high-dose inhaled corticosteroids plus a long-acting beta2 agonist: A randomised double-blind placebo-controlled pivotal phase $2 \mathrm{~b}$ dose-ranging trial. Lancet 2016, 388, 31-44. [CrossRef]

128. Corren, J.; Castro, M.; Chanez, P.; Fabbri, L.; Joish, V.N.; Amin, N.; Graham, N.M.H.; Mastey, V.; Abbe, A.; Taniou, C.; et al. Dupilumab improves symptoms, quality of life, and productivity in uncontrolled persistent asthma. Ann. Allergy Asthma Immunol. 2019, 122, 41-49. [CrossRef]

129. Castro, M.; Corren, J.; Pavord, I.D.; Maspero, J.; Wenzel, S.; Rabe, K.F.; Busse, W.W.; Ford, L.; Sher, L.; FitzGerald, J.M.; et al. Dupilumab Efficacy and Safety in Moderate-to-Severe Uncontrolled Asthma. N. Engl. J. Med. 2018, 378, 2486-2496. [CrossRef]

130. Rabe, K.F.; Nair, P.; Brusselle, G.; Maspero, J.F.; Castro, M.; Sher, L.; Zhu, H.; Hamilton, J.D.; Swanson, B.N.; Khan, A.; et al. Efficacy and Safety of Dupilumab in Glucocorticoid-Dependent Severe Asthma. N. Engl. J. Med. 2018, 378, 2475-2485. [CrossRef]

131. Xiong, X.F.; Zhu, M.; Wu, H.X.; Fan, L.L.; Cheng, D.Y. Efficacy and safety of dupilumab for the treatment of uncontrolled asthma: A meta-analysis of randomized clinical trials. Respir. Res. 2019, 20, 108. [CrossRef]

132. Bachert, C.; Nan, Z. Medical Algorithm: Diagnosis and Treatment of Chronic Rhinosinusitis. Allergy 2019. [CrossRef]

133. Schulman, E.S. Development of a monoclonal anti-immunoglobulin E antibody (omalizumab) for the treatment of allergic respiratory disorders. Am. J. Respir. Crit. Care Med. 2001, 164, S6-S11. [CrossRef]

134. Humbert, M.; Busse, W.; Hanania, N.A.; Lowe, P.J.; Canvin, J.; Erpenbeck, V.J.; Holgate, S. Omalizumab in asthma: An update on recent developments. J. Allergy Clin. Immunol. Pract. 2014, 2, 525-536. [CrossRef]

135. Hanania, N.A.; Wenzel, S.; Rosen, K.; Hsieh, H.J.; Mosesova, S.; Choy, D.F.; Lal, P.; Arron, J.R.; Harris, J.M.; Busse, W. Exploring the effects of omalizumab in allergic asthma: An analysis of biomarkers in the EXTRA study. Am. J. Respir. Crit. Care Med. 2013, 187, 804-811. [CrossRef]

136. Casale, T.B.; Luskin, A.T.; Busse, W.; Zeiger, R.S.; Trzaskoma, B.; Yang, M.; Griffin, N.M.; Chipps, B.E. Omalizumab Effectiveness by Biomarker Status in Patients with Asthma: Evidence From PROSPERO, A Prospective Real-World Study. J. Allergy Clin. Immunol. Pract. 2019, 7, 156-164. [CrossRef]

137. Humbert, M.; Taille, C.; Mala, L.; Le Gros, V.; Just, J.; Molimard, M.; STELLAIR Investigators. Omalizumab effectiveness in patients with severe allergic asthma according to blood eosinophil count: The STELLAIR study. Eur. Respir. J. 2018, 51. [CrossRef]

138. Lambrecht, B.N.; Hammad, H. The role of dendritic and epithelial cells as master regulators of allergic airway inflammation. Lancet 2010, 376, 835-843. [CrossRef]

139. Licona-Limon, P.; Kim, L.K.; Palm, N.W.; Flavell, R.A. TH2, allergy and group 2 innate lymphoid cells. Nat. Immunol. 2013, 14, 536-542. [CrossRef]

140. Corren, J.; Parnes, J.R.; Wang, L.; Mo, M.; Roseti, S.L.; Griffiths, J.M.; van der Merwe, R. Tezepelumab in Adults with Uncontrolled Asthma. N. Engl. J. Med. 2017, 377, 936-946. [CrossRef]

141. Kostenis, E.; Ulven, T. Emerging roles of DP and CRTH2 in allergic inflammation. Trends Mol. Med. 2006, 12, 148-158. [CrossRef] 
142. Erpenbeck, V.J.; Popov, T.A.; Miller, D.; Weinstein, S.F.; Spector, S.; Magnusson, B.; Osuntokun, W.; Goldsmith, P.; Weiss, M.; Beier, J. The oral CRTh2 antagonist QAW039 (fevipiprant): A phase II study in uncontrolled allergic asthma. Pulm. Pharmacol. Ther. 2016, 39, 54-63. [CrossRef]

143. Gonem, S.; Berair, R.; Singapuri, A.; Hartley, R.; Laurencin, M.F.M.; Bacher, G.; Holzhauer, B.; Bourne, M.; Mistry, V.; Pavord, I.D.; et al. Fevipiprant, a prostaglandin D2 receptor 2 antagonist, in patients with persistent eosinophilic asthma: A single-centre, randomised, double-blind, parallel-group, placebo-controlled trial. Lancet Respir. Med. 2016, 4, 699-707. [CrossRef]

144. Bateman, E.D.; Guerreros, A.G.; Brockhaus, F.; Holzhauer, B.; Pethe, A.; Kay, R.A.; Townley, R.G. Fevipiprant, an oral prostaglandin DP2 receptor (CRTh2) antagonist, in allergic asthma uncontrolled on low-dose inhaled corticosteroids. Eur. Respir. J. 2017, 50. [CrossRef]

C 2019 by the authors. Licensee MDPI, Basel, Switzerland. This article is an open access article distributed under the terms and conditions of the Creative Commons Attribution (CC BY) license (http://creativecommons.org/licenses/by/4.0/). 